\title{
Composite-composite adhesion in dentistry: a systematic review and meta-analysis
}

\author{
Özcan, M ; Koc-Dundar, B
}

DOI: https://doi.org/10.1080/01694243.2014.954659

Posted at the Zurich Open Repository and Archive, University of Zurich ZORA URL: https://doi.org/10.5167/uzh-100714

Journal Article

Accepted Version

Originally published at:

Özcan, M; Koc-Dundar, B (2014). Composite-composite adhesion in dentistry: a systematic review and metaanalysis. Journal of Adhesion Science and Technology, 28(21):2209-2229.

DOI: https://doi.org/10.1080/01694243.2014.954659 


\section{Composite-composite Adhesion in Dentistry: A Systematic Review and Meta-analysis}

Mutlu Özcan ${ }^{a}$ / Bilgin Koc-Dundar

${ }^{a}$ Professor, University of Zürich, Dental Materials Unit, Center for Dental and Oral Medicine, Clinic for Fixed and Removable Prosthodontics and Dental Materials Science, Zürich, Switzerland.

${ }^{b}$ Master Student, University of Zürich, Center for Dental and Oral Medicine, Clinic for Fixed and Removable Prosthodontics and Dental Materials Science, Zürich, Switzerland.

Short Title: Review of studies on composite-composite adhesion

${ }^{*}$ Part of this study has been presented at the 91st General Session and Exhibition of the International Association for Dental Research (IADR), March, $20^{\text {th }}-23^{\text {rd }}, 2013$, Seattle, Washington, USA.

Contribution to the paper: Mutlu Özcan designed the study, performed the experiments, analyzed the data and wrote the manuscript, Bilgin Koc-Dundar performed the experiments, analyzed the data, prepared the draft of the manuscript. Both authors discussed the results and commented on the manuscript at all stages. 
Correspondance to: Mutlu Özcan, Prof. Dr.med.dent. Ph.D, University of Zürich, Dental Materials Unit, Center for Dental and Oral Medicine, Clinic for Fixed and Removable Prosthodontics and Dental Materials Science, Plattenstrasse 11, CH-8032, Zürich, Switzerland Tel: +41-44-634-5600; Fax: +41-44-634-4305. e-mail: mutluozcan@hotmail.com

Purpose: Repair or relayering of aged methacrylate resin-based composites with new composites remains a challenge due to the depletion of free radicals in the aged composite after the initial polymerization. Controversy exists in the literature regarding the most optimal repair procedure for improving the adhesion between the repair resin and the existing resin composite materials. This systematic review analyzed the adhesion potential of resin-based composites to similar and dissimilar composites and aimed to determine the possible dominant factors affecting the bond strength results.

Materials and Methods: Original scientific papers on adhesion to composites published in MEDLINE (PubMed) database between 01/01/1955 and 01/06/2010 were included in this systematic review. The following MeSH terms, search terms and their combinations were used: "Composite Resins", "Bond Strength", "Dental Restoration Repair", "Material testing/methods", "Repair". Two reviewers performed screening and data abstraction. Descriptive statistics was performed and the frequencies of the studied parameters, means, standard deviations, Confidence Intervals $(95 \% \mathrm{Cl})$ (uncorrected and corrected) were calculated for the bond strength data reported for different factor levels namely, surface conditioning methods (control, physical, chemical, physico-chemical), substrate-adherent type (being of the same kind or dissimilar), substrate aging (thermocycling or water storage) and test methods (macroshear, microshear, macrotensile, microtensile).

Results: The final search provided 78 titles with abstract. Further abstract screening yielded to 49 articles of which 48 were found potentially appropriate to be included. After abstract reading 1 and full text evaluation, 6 of them were eliminated. The selection process resulted in the final sample of 41 studies. In total, 160 different surface conditioning methods, being mainly combinations of the use of etching agents, application of grinding or air-abrasion 
protocols and adhesive promoters (silanes, adhesive resins), have been investigated. The use of three testing methods namely, macroshear, macrotensile and microtensile, was reported. Substrate composites were aged either in water ranging between 8 and 17520 hours or through thermocycling between 300 and 5000 cycles. When substrate is aged with thermocycling, bond strength results for composite-composite combinations of the same material, were significantly influenced by the surface conditioning method $(p=0.010)$ and with the test method ( $p=0.014$ ) but for dissimilar composite-composite combinations only test method $(p=0.000)$ showed a significant effect on the results. When substrate is aged with water storage, bond strength results for composite-composite combinations of the same material were significantly influenced by the surface conditioning method $(p=0.000)$, but for dissimilar material combinations only test method showed a significant effect $(p=0.000)$ on the results.

Conclusion: Based on the results of this systematic review, for dissimilar substrateadherend combinations, when substrate is aged either with thermocycling or with water storage, not the surface conditioning method but the test method influences the bond strength results. For the composite combinations of the same kind, the impact of surface conditioning type and the test method in thermocycled group was higher on the results. Adhesion studies on composite-composite adhesion and reporting of data require more standardization.

Key words: adhesion, aging, bond strength, composite resin, dental restoration repair, material testing, relayering, repair, surface conditioning, test method. 


\section{INTRODUCTION}

Resin-based composites (hereon: composites) are widely used in dentistry since the progress in adhesive technologies. However, failures of composite restorations are still being reported in clinical studies ranging between $5 \%$ and $45 \%$ during an observation period of 5 to 17 years. ${ }^{13,28}$ Failure of a dental composite is often the result of degradation processes taking place within the polymeric matrix and the silanized filler particles of the composite. The degradation processes are complex and could be due to wear, abrasion, fatigue, enzymatic, hydrolytic, acidic or temperature related breakdown. ${ }^{13,57}$ When a composite restoration fails as a result of discoloration, micro-leakage, ditching at the margins, delamination or simply due to cohesive fracture, the restoration needs to be repaired or replaced. ${ }^{5,25,41}$ Total replacement of the restoration is the most common procedure experienced in daily clinical practice. ${ }^{45,60,64}$ However, this approach may be regarded as over-treatment when large portions of the restorations is clinically and radiographically considered free of failures. Moreover, complete removal of a failed restoration would generally entail removal of enamel and/or dentin leading to more loss of sound dental tissues that could inevitably result in weakening of the tooth or injuries to the 
pulp. ${ }^{41}$ In such cases, repair actions would preserve the tooth as it is often difficult to remove a tooth-colored adhesive restoration without removing an integral part of the tooth.

In general, adhesion between two composite layers is achieved in the presence of an oxygen-inhibited layer of unpolymerized $\operatorname{resin} .^{72}$ While in previous studies, it was stated that $40-50 \%$ of the unreactive methacrylate groups are present after photo-polymerization of the composites that allow for adhesion of new resin layers, unreactive methacrylate groups are reported to be reduced with time, thereby reducing the potential for bonding of resins. ${ }^{46}$ Therefore, a great variety of surface conditioning methods and adhesion promoters have been proposed to improve the composite-composite adhesion such as roughening by burs, etching the substrate surface with acidic compounds, ${ }^{17}$ air-borne particle abrasion, ${ }^{23,42,62,72}$ or using intermediate adhesive resins. ${ }^{17,18,37}$ Although promising results were obtained with some of these surface conditioning methods in earlier studies, the tests were often performed on non-aged substrates where the results could be considered optimistic and do not represent the real-life clinical situations. Furthermore, earlier studies were often performed using the same type of composite as both the substrate and the adherend material. $^{6,21,54-56,58,72}$ This may not always represent the clinical situation. When a composite restoration fails and the patient has visited several dentists, it is not always possible to trace the information as to which composite material was used and under which conditions it was polymerized. In some occasions, even the restorative composite itself may no longer be launched. For this reason, often in the clinical situation, dissimilar composite materials are adhered to each other during repair. ${ }^{45}$ Several studies demonstrated that the compositecomposite repair strengths could reach $20-80 \%$ of the initial bond strength, depending on the cohesive resistance of the material. ${ }^{1,22,72}$ In contrast to the repair of immediately polymerized composites, repair of aged composites represents a challenge due to the depletion of free radicals in the aged composite after the initial polymerization. ${ }^{5,64}$ 
Even though the literature presents comparative studies, controversy exists regarding to the best surface conditioning method for optimum repair strength of composites. Moreover, aging of the substrate may affect the results. Since the test parameters vary considerably among the available published studies, there is apparent need to develop some guidelines in testing and interpreting the data on adhesion to composites.

The objective of this systematic review therefore was to analyze the adhesion potential of resin-based composites to the composites of the same kind or dissimilar ones and aimed to determine the possible dominant factors affecting the bond strength results.

\section{MATERIALS AND METHODS}

\section{Search Strategy}

Before the initiation of the literature search, a protocol to be followed was agreed upon by the authors. An electronic search at MEDLINE (PubMed) (http://www.ncbi.nlm.nih.gov/entrez/query.fcgi) from 01/01/1955 and 01/06/2010 was conducted for English-language articles published in the dental literature, using the following MeSH terms, search terms and their combinations: "Composite Resins", "Bond Strength", "Dental Restoration Repair", "Material testing/methods", "Repair". The MEDLINE search yielded 78 references to be screened for possible inclusion based on titles and abstracts (Table 1). A further manual search covering the period from 01/01/1955 up to and including 01/06/2010 was performed on the following journals: Journal of Dental Research, Dental Materials, Journal of Adhesive Dentistry, International Journal of Prosthodontics, Journal of Prosthetic Dentistry, Journal of Prosthodontics, and Journal of Biomedical Materials Research Part B: Applied Biomaterials. In addition, hand searches were performed on bibliographies of the selected articles as well as identified narrative reviews to find out 
whether the search process has missed any relevant article. This did not add to new additional articles to be involved in the review process.

\section{Inclusion/Exclusion Criteria}

In vitro studies reporting on adhesion to composite materials using macroshear, microshear, macrotensile, or microtensile, were included. Publications were excluded if composite was adhered onto tooth substance, data were not presented in MPa and temporary restorations were used. Also, studies performed with pull-out test were not included.

\section{Selection of Studies}

Two independent reviewers (B.K-D. and M.Ö.) screened the 78 titles retrieved from the electronic search for possible inclusion in the review. After initial elimination, based on the titles and the abstracts, 48 abstracts were accepted for inclusion by both reviewers. After discussion, a consensus was reached to include 47 articles. Full-text articles were obtained of the 41 selected publications. The two reviewers independently assessed the 41 full-text articles to determine whether they fulfilled the defined criteria for final inclusion. Any disagreement was resolved by discussion. Forty-one studies were found to qualify for inclusion in the review, while 6 articles had to be excluded after full text reading. Process of identifying the studies included in the review from an initial 78 titles is presented in Fig. 1.

\section{Data Extraction}

The two reviewers extracted data independently using a data extraction form previously agreed upon. A data collection form containing 37 items was created and used to assess the experimental conditions that may possibly affect the bond strength. Disagreement regarding data extraction was resolved by discussion and a consensus was reached. The variables were recorded and tabulated in Excel sheets. Studies in which data on a certain variable 
were lacking or could not be calculated were scored as 'not reported' for the variable in question.

\section{Statistical Analysis}

Statistical analyses were performed using the Statistical Package for the Social Sciences (version 18.0, SPSS Inc, Chicago, IL, USA). The inter-observer agreement with respect to the reporting of experimental conditions of the included abstracts before the consensus meeting is expressed as weighted Cohen's kappa. For descriptive statistics means and standard deviations, or medians and interquartile ranges in skewed distributions were noted. The frequencies of the studied parameters were calculated. Weighted mean values and the 95\% confidence interval $(\mathrm{Cl})$ for the various outcomes were calculated. Confidence Intervals $(95 \% \mathrm{Cl})$ (uncorrected and corrected) were calculated for mean bond strength for different factor levels, namely for surface conditioning methods (control, physical, chemical, physicochemical), substrate-adherent type (being of the same kind or dissimilar), substrate aging (thermocycling or water storage) and test methods (macroshear, microshear, macrotensile, microtensile). $P$ values smaller than 0.05 , were considered to be statistically significant in all comparisons.

\section{RESULTS}

\section{Characteristics of the Included/Excluded Studies}

The publications qualified for inclusion are presented in Table 2. The Kappa score for agreement between the reviewers for screening of abstracts was 0.85 . In the selected 41 articles, $4,6,8-12,19-21,23,27,29,32,34,36,38,44-50,52-54,58,61,60,63,65-67,70,74-76$ a total of 506 experimental subgroups were identified where bond strength results were reported in MPa. In all selected subgroups, the search identified great variety of surface conditioning protocols with 160 different methods to condition composite surfaces prior to composite adhesion (Table 3). 
Of the selected 41 articles, substrate aging was more commonly performed using water storage at varying durations ( 8 to 17520 hours) ( $n=312$ subgroups) than thermocycling ( $n=84$ subgroups) (300-5000 cycles). Physico-chemical conditioning method was more frequently used than physical and chemical conditioning methods. Among test methods, macroshear test was more often used than other test methods. No studies were identified where microshear test was performed. Table 4 shows descriptive statistics on the different parameters tabulated from the selected studies according to the surface conditioning method, aging conditions for the substrate and the test method.

The major findings based on the substrate-adherent combination were as follows:

\section{Adhesion to Composite Substrates Aged with Thermocycling}

When substrate is aged with thermocycling, bond strength results for composite-composite combinations of the same material, were significantly influenced by the surface conditioning method $(p=0.010)$ and with the test method $(p=0.014)$ (Table 5a) but for dissimilar composite-composite combinations only test method $(p=0.000)$ showed a significant effect on the results (Table 5b).

Adhesion of composite-composite combinations of the same substrate-adherend composite materials benefitted similarly from all types of conditioning methods. Compared to microtensile test method, macroshear $(p=0.000)$ and macrotensile $(p=0.025)$ tests showed significantly lower results. In the macroshear test, non-thermocycled group showed significantly higher results $(p=0.001)$ compared to thermocycled group (Table 6a).

Adhesion of composite-composite combinations of dissimilar substrate-adherend composite materials also benefitted similarly from all types of conditioning methods. Compared to mictotensile test method, macroshear $(p=0.004)$ and macrotensile $(p=0.001)$ tests showed significantly lower results. Thermocycling significantly decreased the results for the bond strength of dissimilar substrate-adherend composite combinations $(p=0.013)$. 
Physical surface conditioning showed significantly higher results for macroshear $(p=0.012)$ than macrotensile test method. Chemical surface conditioning in macroshear test, showed significantly lower $(p=0.006)$ results compared to microtensile test (Table $6 b)$.

\section{Adhesion to Composite Substrates Aged with Water Storage}

When substrate is aged with water storage, bond strength results for composite-composite combinations of the same material were significantly influenced by the surface conditioning method $(p=0.000)$, but for dissimilar material combinations only test method showed a significant effect $(p=0.000)$ on the results (Tables 7a-b).

Adhesion of composite-composite combinations of the same material showed significantly lower results in non-conditioned $(p=0.039)$ and chemically conditioned $(p=0.000)$ groups compared to physical and physicochemical conditioning. Macroshear $(p=0.000)$ and macrotensile $(p=0.010)$ tests presented significantly higher results compared to microtensile test (Table $8 a)$. Water storage $(p=0.008)$ significantly decreased the results compared to non-water stored groups. Chemical surface conditioning method in the macroshear test showed significantly lower results $(p=0.042)$ compared to chemical conditioning in microtensile test. Using macroshear test, non-aged control groups presented significantly $(p=0.000)$ higher results compared to aged conditions.

Adhesion of composite-composite combinations of dissimilar materials, using physical conditioning method showed significantly lower results $(p=0.022)$ than physicochemical conditioning (Table 8b). Macroshear $(p=0.002)$ and macrotensile tests $(p=0.002)$ showed significantly lower results than with microtensile test. Water storage did not significantly $(p=$ 0.156) affect the results compared to non-water stored groups. Physical surface conditioning in macroshear test showed significantly lower results $(p=0.005)$ compared to macrotensile test. Chemical conditioning in macroshear test presented significantly lower bond strength results compared to microtensile test $(p=0.002)$. 


\section{DISCUSSION}

Repair or relayering of composite materials is an integral part of dynamic treatment concept and serves for maintenance of such restorations without sacrificing from dental tissues during replacement actions. Composite materials need to be repaired either at early or late phases after their placement. Due to lack of experience with the specific material, inadequate shade selection or mismatch between the restored and the adjacent teeth can be corrected by relayering procedures. In this case, the composite materials are not aged and therefore adding a new layer of composite onto an existing, already polymerized composite does not present much of a problem during layering in the same session and could be considered as early repairs. ${ }^{39}$ On the other hand, degradation of the composite surfaces that could be considered as a multifactorial clinical problem could result in aging of the material. Although clinicians spend $70 \%$ of their chairside time replacing restorations, ${ }^{41}$ with the introduction of adhesive technologies, the service life of even such restorations could be prolonged. When composite is polymerized under the air, an oxygen-inhibited layer is always present. This layer contains unreacted acrylate groups which improve adhesion between the substrate and the second layer by the formation of covalent bonds. ${ }^{35,64,68,69}$ In fact, in aged conditions, active free radicals may be expected to be less. Since both early and late repair actions are of clinical interest for the aim of reducing the restoration cycle, mainly due to variations in testing environments, no consensus has been established in recommending the best repair protocol for early and late repairs. Hence, this systematic review aimed for analyzing the published literature in the field of composite repairs in dentistry and make suggestions for future investigations. 
Typically the composite materials used in dental applications are based on methacrylate resins. While different aging procedures have been tried in the dental literature, in this review only thermocycling and water storage have been considered as aging regimens. Despite the fact that water storage simulates aging due to water uptake only, thermocycling represents hydrothermal aging. Temperature changes and repetitive contraction-expansion stresses that occur in the composite materials could have a significant impact on the adhesion of the subsequent composite layer. In the selected studies, water storage hours showed a big variation between 8 and 17520 hours corresponding to 0.33 and 730 days, respectively. Water sorption level of composites certainly varies depending on their filler content in relation to the methacrylate monomer matrix and after a certain point saturation could be expected. In that respect, almost 2 years of water storage has undoubtedly a different effect than storage for less than a day. Variations in standard deviations could easily be attributed to this factor. Nevertheless, statistical analysis indicated that water storage did not significantly affect the results compared to non-water stored groups. In that respect, aging with thermocycling demonstrated more detrimental effect on the bond strength results.

Since thermocycling could be considered to represent worse case aging scenario, the data extraction was performed only from non-thermocycled (dry stored) and thermocycled groups. The number of cycling also for thermocycling groups showed a big variation ranging between 300 and 5000 cycles. Similar to water storage groups, the results presented here showed high standard deviations. According to the ISO norm $10477,{ }^{33}$ minimum number of thermocycling was proposed as 5000 cycles to assess metal-resin bond. To the authors best knowledge, such a standard does not exist for aging composite materials or for aging composite-composite adhesion. Therefore, some standardization on the aging protocols for composite materials seems to be crucial. The frequency of cycles in vivo remains to be 
determined at present and requires formal estimation. On the basis that such cycles might occur between 20 and 50 times a day, it is proposed that 10.000 cycles might represent one year of in vivo functioning. ${ }^{17,24}$ Based on the evaluated studies, aging composites in water storage ( $n=312$ subgroups) was a more common practice compared to thermocycling $(n=84$ subgroups). This may relate to the availability of this device where the studies were conducted. Nonetheless, when substrate composite was aged either with thermocycling or with water storage and bonded with the same composite material, surface conditioning methods and in particular physicochemical conditioning methods showed a significant impact on the bond strength results.

In the selected 41 articles, a total of 506 experimental subgroups were identified with a great variety of surface conditioning protocols, namely 160 different methods were used to condition the composite surfaces prior to adhering the subsequent composite material. Physico-chemical conditioning method was more frequently used than physical and chemical conditioning methods. The prerequisite for effective adhesion of polymeric materials onto any substance is to achieve a clean surface free of contaminants. In previous studies, the success of composite-to-composite adhesion was reported to depend on the chemical composition of the surface, its roughness, wettability, and the surface conditioning procedures applied. $^{3,7,30,31,44,69}$ In the reviewed articles, while in the majority of the studies composite surfaces were typically grinded with silicone carbide abrasive papers ranging between 60 and 1200-grit, others started with cleaning the surfaces using etching solutions. In fact, surface conditioning takes place already with the grinding processes and the starting surface roughness may have an impact on the results.

Since a great plethora of conditioning methods were noted, in this review they were categorized in four groups only. The particle deposition techniques or the use of burs were considered as physical conditioning methods. The abrasives used were often $\mathrm{Al}_{2} \mathrm{O}_{3}$ or $\mathrm{SiO}_{2}$ 
particles with particle size ranging between 25 and $50 \mu \mathrm{m}$. Air-abrasion methods clean the surface and increase the surface energy. The pressure and duration of the deposition are important parameters to consider in achieving an optimal roughness. ${ }^{43}$ The results in general indicated that physico-chemical conditioning methods regardless of such airabrasion related parameters tend to increase the bond strength values for composites. Yet, the results of this review based on the available data indicated that compared to the control groups where no conditioning was practiced, physical conditioning with air-abrasion seems to increase the composite-composite bond strength.

Several testing methodologies such as macroshear, microshear, macrotensile, and microtensile tests have been suggested for evaluation of the bond strength of resin-based materials to different substrates in dentistry. It is critical that the bonding interface should be the most stressed region, regardless of the test methodology being employed. Previous studies using stress distribution analyses have reported that some bond strength tests do not appropriately stress the interfacial zone. ${ }^{14-16,73}$ Shear tests have been criticized for the development of non-homogeneous stress distributions in the bonded interface, inducing either underestimation or misinterpretation of the results, as the failure often starts in one of the substrates and not at the adhesive zone. ${ }^{14,15,73}$ Although conventional tensile tests also present some limitations, such as the difficulty of specimen alignment, this type of test was proposed to provide information on global bond strength. ${ }^{14}$ Microtensile test allows better alignment of the specimens, and a more homogeneous distribution of stress, in addition to a more sensitive comparison or evaluation of bond performances. ${ }^{2}$ This systematic review indicated that against the limitations of shear tests, macroshear test continues to be more commonly applied. No studies were identified where microshear test was performed. Particularly for dissimilar composite-composite combinations, test method had a significant effect on the bond strength results both in thermocycled or water stored groups. The highest 
bond strength results were obtained from microtensile tests followed by macroshear and macrotensile tests in both thermocycled and water-aged groups. In the macro shear test, for both composite-composite combinations of similar and dissimilar composites nonthermocycled group showed significantly higher results compared to thermocycled group, clearly indicating the aging effect of thermocycling. Although initially intended, failure type analysis could not be classified in this review due to inconsistency.

Clinically sufficient bond strength value is not known for composite-composite adhesion. The great variation in testing parameters and testing environment would continue to create the confusion in the dental literature. Since in the future new studies are expected to appear in this field, the following points could be suggested:

- The steps of conditioning methods should be defined precisely.

- A consensus needs to be made on aging parameters.

- Exact composition of the composites should be given.

- Composite-composite bond strength should be verified with different test methods in one study.

- The bond strength data should be presented with confidence intervals, mean, minimum and maximum values.

- $\quad$ Failure types after bond tests should be listed in detail.

\section{CONCLUSIONS}

From this review, the following could be concluded:

1. Current studies regarding the composite-composite adhesion should be evaluated cautiously considering the surface conditioning method, aging conditions of the substrate composite and the employed test method. Some more systematic approach especially regarding to aging conditions is needed when studying adhesion to composites. 
2. Future adhesion studies to composites should implement a non-conditioned control group with exact definition of the conditioning protocol.

3. For dissimilar substrate-adherend combinations, when substrate is aged either with thermocycling or with water storage, the surface conditioning method seems to be insignificant but the test method influences the bond strength results.

4. For the composite combinations of the same kind, the impact of surface conditioning type was more significant.

5. Surface conditioning methods and in particular physico-chemical conditioning methods, increased the composite-composite bond strength.

\section{Clinical relevance:}

For durable repair or relayering of aged composites, physico-chemical surface conditioning of the substrate composite seems to be essential.

\section{Acknowledgement}

The authors acknowledge Mrs. H. Eschle, University of Zürich, Center for Dental and Oral Medicine, Zürich, Switzerland, for her assistance with the library facilities and Mrs. M. Roos,

from the Division of Biostatistics, Institute of Social and Preventive Medicine, University of Zurich, Switzerland for her support with the statistical analysis.

\section{REFERENCES}

1. Azarbal P, Boyer DB, Chan KC. The effect of bonding agents on the interfa- cial bond strength of repaired composites. Dent Mater 1986;2:153-155.

2. Betamar N, Cardew G, Van Noort R. Influence of specimen designs on the microtensile bond strength to dentin. J Adhes Dent 2007;9:159-168. 
3. Bouschlicher MR, Reinhardt JW, Vargas MA. Surface treatment techniques for resin composite composite/bonding agent combinations. Oper Dent 1991;16:136-140.

4. Bouschlicher MR, Reinhardt JW, Vargas MA. Surface treatment techniques for resin composite repair. Am J Dent 1997;10:279-283.

5. Boyer DB, Chan KC, Reinhardt JW. Build-up and repair of light-cured com- posites: bond strength. J Dent Res 1984;63:1241-1244.

6. Brendeke J, Özcan M. Effect of physicochemical aging conditions on the compositecomposite and indirect composite resins. J Prosthet Dent 1992;68:406-411.

7. Brosh T, Pilo R, Bichacho N, Blutstein R. Effect of combinations of surface treatments and bonding pretreated aged composites used in some indirect bonding techniques. J Dent Res 1993;72:1291-1297.

8. Brosh T, Pilo R, Bichacho N, Blutstein R. Effect of combinations of surface treatments and bonding agents on the bond strength of repaired composites. J Prosthet Dent 1997;77:122126.

9. Chen HL, Lai YL, Chou IC, Hu CJ, Lee SY. Shear bond strength of provisional restoration materials repaired with light-cured resins. Oper Dent 2008;33:508-515.

10. Costa TR, Ferreira SQ, Klein-Júnior $C A$, Loguercio $A D$, Reis A. Durability of surface treatments and intermediate agents used for repair of a polished composite. Oper Dent 2010;35:231-237.

11. Dall'Oca S, Papacchini F, Goracci C, Cury AH, Suh BI, Tay FR, Polimeni A, Ferrari M. Effect of oxygen inhibition on composite repair strength over time. J Biomed Mater Res B Appl Biomater 2007;81:493-498.

12. Dall'oca S, Papacchini F, Radovic I, Polimeni A, Ferrari M. Repair potential of a laboratory-processed nano-hybrid resin composite. J Oral Sci 2008;50:403-412. 
13. da Rosa Rodolpho PA, Cenci MS, Donassollo TA, Loguercio AD, Demarco FF. A clinical evaluation of posterior composite restorations: 17-year findings. J Dent 2001;34:427-435.

14. DeHoff PH, Anusavice KJ, Wang Z. Three-dimensional finite element analysis of the shear bond test. Dent Mater 1995;11:126-131.

15. Della Bona A, Van Noort R. Shear vs. tensile bond strength of resin composite bonded to ceramic. J Dent Res 1995;74:1591-1596.

16. Della Bona A, Anusavice KJ, Hood JAA. Effect of ceramic surface treatment on tensile bond strength to a resin cement. Int J Prosthodont 2002;15:248-253.

17. Denehy G, Bouschlicher M, Vargas M. Intraoral repair of cosmetic restorations. Dent Clin North Am 1998;42:719-737.

18. Dias WR, Ritter AV, Swift EJ Jr. Repairability of a packable resin-based com- posite using different adhesives. Am J Dent 2003;16:181-185.

19. El-Askary FS, Fawzy AS, Abd Elmohsen HM. Tensile bond strength of immediately repaired anterior microfine hybrid restorative composite using nontrimmed hourglass specimens. J Adhes Dent 2009;11:41-47.

20. Fawzy AS, El-Askary FS, Amer MA. Effect of surface treatments on the tensile bond strength of repaired water-aged anterior restorative micro-fine hybrid resin composite. J Dent 2008;36:969-976.

21. Flores S, Charlton DG, Evans DB. Repairability of polyacid-modified composite resin. Oper Dent composite resin. Oper Dent 1999;24:371-376.

22. Frankenberger R, Krämer N, Ebert J, Lohbauer U, Käppel S, ten Weges S, Petschelt A. Fatigue polymeric composites. Dent Mater 2001;17:80-86. 
23. Frankenberger R, Kramer N, Ebert J, Lohbauer U, Kappel S, ten Weges S, Petschelt A. Fatigue behavior of the resin-resin bond of partially replaced resin-based composite restorations. Am J Dent 2003;16:17-22.

24. Gale M, Darvell B. Thermal cycling procedures for laboratory testing of dental restorations. J Dent 1999;27:89-99.

25. Gordan VV, Shen C, Riley J 3rd, Mjor IA. Two-year clinical evaluation of repair versus replacement of composite restorations. J Esthet Restor Dent 2006;18:144-153.

26. Gregory WA, Berry S, Duke E, Dennison JB. Physical properties and repair bond strength of direct and indirect composite resins. J Prosthet Dent 1992;68:406-411.

27. Hannig C, Laubach S, Hahn P, Attin T. Shear bond strength of repaired adhesive filling materials using different repair procedures. J Adhes Dent 2006;8:35-40.

28. Hickel R, Manhart J. Longevity of restorations in posterior teeth and reasons for failure. J Adhes Dent 2001;3:45-64.

29. Hisamatsu N, Atsuta M, Matsumura H. Effect of silane primers and unfilled resin bonding agents on repair bond strength of a prosthodontic microfilled composite. J Oral Rehabil 2002;29:644-648.

30. Hisamatsu N, Atsuta M, Matsumura H. Effect of silane primers and unfilled resin bonding agents on behavior of the resin-resin bond of partially replaced resin-based composite restorations. Am J Dent 2003;16:17-22.

31. Hisamatsu N, Tanoue N, Yanagida H, Atsuta M, Matsumura H. Twenty-four hour bond strength composite repair. Oper Dent 2003;28:149-154.

32. Hisamatsu N, Tanoue N, Yanagida H, Atsuta M, Matsumura H. Twenty-four hour bond strength between layers of a highly loaded indirect composite. Dent Mater J 2005;24:440446. 
33. International Organization For Standardization, Metal-resin adhesion, Amendment 1, ISO 10477. Geneva, 1996.

34. Kallio TT, Lastumäki TM, Vallittu PK. Bonding of restorative and veneering composite resin to some polymeric composites. Dent Mater 2001;17:80-86.

35. Kula K, Nelson S, Kula T, Thompson V. In vitro effect of acidulated phosphate fluoride gel on the surface of composites with different filler particles. J Prosthet Dent 1986;56:161-9. 36. Lassila LV, Tezvergil A, Dyer SR, Vallittu PK. The bond strength of particulate-filler composite to differently oriented fiber-reinforced composite substrate. J Prosthodont 2007;16:10-17.

37. Lastumaki TM, Kallio TT, Vallittu PK. The bond strength of light-curing composite resin to finally polymerized and aged glass fiber-reinforced composite substrate. Biomater 2002;23:4533-4539.

38. Lewis G, Johnson W, Martin W, Canerdy A, Claburn C, Collier M. Shear bond strength of immediately repaired light-cured composite resin restorations. Oper Dent 1998;23:121-127. 39. Lewis G, Johnson W, Martin W, Canerdy A, Claburn C, Collier M. Shear bond strength of composite. Am J Dent 2004;17:173-176.

40. Lucena-Martín C, González-López S, Navajas-Rodríguez de Mondelo JM. The effect of various surface treatments and bonding agents on the repaired strength of heat-treated composites. J Prosthet Dent 2001;86:481-488.

41. Mjør IA. Placement and replacement of restorations. OperDent 1981;6:49-54.

42. Özcan M. Evaluation of alternative intra-oral repair techniques for fractured ceramicfused-to-metal restorations. J Oral Rehabil 2003;30:194-203.

43. Özcan M, Lassila LVL, Raadschelders J, Matinlinna JP, Vallittu PK. Effect of some parameters on silica-deposition on a zirconia ceramic. J Dent Res 2005;84;Special Issue A; (Abstract\#545). 
44. Özcan M, Alander P, Vallittu PK, Huysmans MC, Kalk W. Effect of three surface conditioning methods to improve bond strength of particulate filler resin composites. J Mater Sci Mater Med 2005;16:21-27.

45. Özcan M, Barbosa SH, Melo RM, Galhano GA, Bottino MA. Effect of surface conditioning methods bonding systems in combination with various composites used for repairing aged composites. J Adhes Dent 2005;7:159-164.

46. Öztas N, Alacam A, Bardakçi Y. The effect of air abrasion with two new bonding agents on using different repair procedures. J Adhes Dent 2006;8:35-40.

47. Papacchini F, Dall'Oca S, Chieffi N, Goracci C, Sadek FT, Suh BI, Tay FR, Ferrari M. Composite-to-composite microtensile bond strength in the repair of a microfilled hybrid resin: effect of surface treatment and oxygen inhibition. J Adhes Dent 2007;9:25-31.

48. Papacchini F, Monticelli F, Hasa I, Radovic I, Fabianelli A, Polimeni A, Ferrari M. Effect of air-drying temperature on the effectiveness of silane primers and coupling blends in the repair of a microhybrid resin composite. J Adhes Dent 2007;9:391-397.

49. Papacchini F, Monticelli F, Radovic I, Chieffi N, Goracci C, Tay FR, Polimeni A, Ferrari M. The application of hydrogen peroxide in composite repair. J Biomed Mater Res B Appl Biomater 2007;82:298-304.

50. Papacchini F, Radovic I, Magni E, Goracci C, Monticelli F, Chieffi N, Polimeni A, Ferrari M. Flowable composites as intermediate agents without adhesive application in resin composite repair. Am J Dent 2008;21:53-58.

51. Papacchini F, Toledano M, Monticelli F, Osorio R, Radovic I, Polimeni A, García-Godoy F, Ferrari M. Hydrolytic stability of composite repair bond. Eur J Oral Sci 2007;115:417-424.

52. Perriard J, Lorente MC, Scherrer S, Belser UC, Wiskott HW. The effect of water storage, elapsed time and contaminants on the bond strength and interfacial polymerization of a nanohybrid composite. J Adhes Dent 2009;11:469-478. 
53. Puckett AD, Holder R, O'Hara JW. Strength of posterior composite repairs using different composite/bonding agent combinations. Oper Dent 1991;16:136-140.

54. Rinastiti M, Özcan M, Siswomihardjo W, Busscher HJ. Immediate repair bond strengths of microhybrid, nanohybrid and nanofilled composites after different surface treatments. J Dent 2010;38:29-38.

55. Rinastiti M, Özcan M, Siswomihardjo W, Busscher HJ, van der Mei HC. Effect of biofilm on the repair bond strengths of composites. J Dent Res 2010;89:1476-1481.

56. Rinastiti M, Özcan M, Siswomihardjo W, Busscher HJ. Effects of surface conditioning on repair bond strengths of non-aged and aged microhybrid, nanohybrid, and nanofilled composite resins. Clin Oral Investig 2011;15:625-633.

57. Roulet J-F Degradation of dental polymers. Karger, Basel, 1987, p. 40-52.

58. Sau CW, Oh GS, Koh H, Chee CS, Lim CC. Shear bond strength of repaired composite resins using repaired with light-cured resins. Oper Dent 2008;33:508-515.

59. Shahdad SA, Kennedy JG. Bond strength of repaired anterior composite resins: an in vitro study. J Dent 1998;26:685-694.

60. Shahdad SA, Kennedy JG. Bond strength of repaired anterior composite resins: an in vitro study. J processed nano-hybrid resin composite. J Oral Sci 2008;50:403-412.

61. Shiau JY, Rasmussen ST, Phelps AE, Enlow DH, Wolf GR. Analysis of the shear bond strength of pretreated aged composites used in some indirect bonding techniques. J Dent Res 1993;72:1291-1297.

62. Soderholm KJ, Roberts MJ. Variables influencing the repair strength of dental composites. Scand J Dent Res 1991;99:173-180.

63. Souza EM, Francischone CE, Powers JM, Rached RN, Vieira S. Effect of different surface treatments on the repair bond strength of indirect composites. Am J Dent 2008;21:93-96. 
64. Swift EJ Jr, LeValley BD, Boyer DB. Evaluation of new methods for composite repair. Dent Mater 1992;8:362-5.

65. Teixeira EC, Bayne SC, Thompson JY, Ritter AV, Swift EJ. Shear bond strength of selfetching bonding systems in combination with various composites used for repairing aged composites. J Adhes Dent 2005;7:159-164.

66. Tezvergil A, Lassila LV, Vallittu PK. Composite-composite repair bond strength: effect of different adhesion primers. J Dent 2003;31:521-525.

67. Tezvergil A, Lassila LV, Yli-Urpo A, Vallittu PK. Repair bond strength of restorative resin composite applied to fiber-reinforced composite substrate. Acta Odontol Scand 2004;62:5160.

68. Tezvergil A, Lassila LV, Vallittu PK. Composite-composite repair bond strength: effect of different microfine hybrid restorative composite using nontrimmed hourglass specimens. $\mathrm{J}$ Adhes Dent 2009;11:41-7.

69. Tezvergil A, Lassila LV, Yli-Urpo A, Vallittu PK. Repair bond strength of restorative resin composite time and contaminants on the bond strength and interfacial polymerization of a nanohybrid composite. J Adhes Dent 2009;11:469-478.

70. Trajtenberg CP, Powers JM. Effect of hydrofluoric acid on repair bond strength of a laboratory composite. Am J Dent 2004;17:173-176.

71. Turner CW, Meiers JC. Repair of an aged, contaminated indirect composite resin with a direct, visible-light-cured composite resin. Oper Dent 1993;18:187-194.

72. Vankerckhoven H, Lambrechts P, van Beylen M, Davidson CL, Vanherle G. Unreacted methacrylate groups on the surfaces of composite resins. J Dent Res 1982;61:791-795.

73. Versluis A, Tantbirojn D, Douglas WH. Why do shear bond tests pull out dentin? J Dent Res 1997;76:1298-1307. 
74. Vivas J, Yaman P, Taylor G. Effect of different surface treatments on the shear and flexural re-bond strengths of a micro-hybrid composite. J Contemp Dent Pract 2009;10:E001-8.

75. Yap AU, Sau CW, Lye KW. Effects of aging on repair bond strengths of a polyacidmodified composite resin. Oper Dent 1999;24:371-376.

76. Yesilyurt C, Kusgoz A, Bayram M, Ulker M. Initial repair bond strength of a nano-filled hybrid resin: effect of surface treatments and bonding agents. J Esthet Restor Dent 2009;21:251-260.

\section{Captions to tables and figures:}

\section{Tables}

Table 1. Search strategy in MEDLINE applied for this review. \#: search, MeSH: Medical subjects heading, a thesaurus word.

Table 2. Articles selected for the review that met the inclusion criteria.

Table 3. Sequence of surface conditioning methods used for composite resins as stated by the authors.

Table 4. Descriptive statistics on the different parameters tabulated from the selected studies according to the surface conditioning methods, aging conditions for the substrate and the test method. 
Tables 5a-b. Significant effects of surface conditioning methods, test methods and their interactions on mean bond strengths for thermocycled groups for substrate-adherent type of a) being of the same kind (Substrate=Adherent) or b) dissimilar (Substrate $\neq$ Adherent).

Tables 6a-b. Significant differences for cross-comparisons and interactions between surface conditioning methods, test methods for thermocycled groups for substrate-adherent type of a) being of the same kind (Substrate=Adherent) or b) dissimilar (Substrate $\neq$ Adherent).

Tables 7a-b. Significant effects of surface conditioning methods, test methods and their interactions on mean bond strengths for water stored groups for substrate-adherent type of a) being of the same kind (Substrate=Adherent) or b) dissimilar (Substrate $\neq$ Adherent).

Tables 8a-b. Significant differences for cross-comparisons and interactions between surface conditioning methods, test methods for water stored groups for substrate-adherent type of a) being of the same kind (Substrate=Adherent) or b) dissimilar (Substrate₹Adherent).

\section{Figures}

Fig. 1 Process of identifying the studies included in the review.

Figs. 2a-f Mean bond strength (MPa) for substrate-adherent adhesion of the same kind (Substrate=Adherent) with and without thermocycling of the substrate after macroshear, macrotensile and microtensile tests.

Figs. 3a-f Mean bond strength (MPa) for substrate-adherent adhesion of dissimilar composites (Substrate $\neq$ Adherent) with and without thermocycling of the substrate after macroshear, macrotensile and microtensile tests. 
Figs. 4a-f Mean bond strength (MPa) for substrate-adherent adhesion of the same kind (Substrate=Adherent) with and without water storage of the substrate after macroshear, macrotensile and microtensile tests.

Figs. 5a-f Mean bond strength (MPa) for substrate-adherent adhesion of dissimilar composites (Substrate $\neq$ Adherent) with and without water storage of the substrate after macroshear, macrotensile and microtensile tests. 


\section{Legends}

\section{Tables:}

Table 1. Search strategy in MEDLINE applied for this review. \#: search, MeSH: Medical subjects heading, a thesaurus word.

\begin{tabular}{|l|l|l|}
\hline Search & Literature search strategy & Results \\
\hline 1 & "Composite Resins" [MeSH] & 19753 \\
\hline 2 & "Composite Resins" & 386 \\
\hline 3 & "Bond Strength" & 206 \\
\hline 4 & "Dental Restoration Repair" [MeSH] & 0 \\
\hline 5 & "Repair" & 0 \\
\hline 6 & "Material Testing/Methods" [MeSH] & 3849 \\
\hline 7 & $\begin{array}{l}\text { (“1995/01/01"[Publication Date]: "2010/06/01" "[Publication Date]) AND (((((\#1) } \\
\text { AND \#2) AND \#3) AND \#6) }\end{array}$ & 78 \\
\hline
\end{tabular}


Table 2 Articles selected for the review that met the inclusion criteria.

\begin{tabular}{|c|c|}
\hline Number & Source listed chronologically \\
\hline 1 & $\begin{array}{l}\text { Puckett AD, Holder R, O'Hara JW. Strength of posterior composite repairs using different composite/bonding } \\
\text { agent combinations. Oper Dent 1991;16:136-40. }\end{array}$ \\
\hline 2 & $\begin{array}{l}\text { Gregory WA, Berry S, Duke E, Dennison JB. Physical properties and repair bond strength of direct and } \\
\text { indirect composite resins. J Prosthet Dent 1992;68:406-411. }\end{array}$ \\
\hline 3 & $\begin{array}{l}\text { Shiau JY, Rasmussen ST, Phelps AE, Enlow DH, Wolf GR. Analysis of the shear bond strength of pretreated } \\
\text { aged composites used in some indirect bonding techniques. J Dent Res 1993;72:1291-1297. }\end{array}$ \\
\hline 4 & $\begin{array}{l}\text { Flores S, Charlton DG, Evans DB. Repairability of polyacid-modified composite resin. Oper Dent } \\
\text { 1995;20:191-196. }\end{array}$ \\
\hline 5 & $\begin{array}{l}\text { Brosh T, Pilo R, Bichacho N, Blutstein R. Effect of combinations of surface treatments and bonding agents on } \\
\text { the bond strength of repaired composites. J Prosthet Dent 1997;77:122-126. }\end{array}$ \\
\hline 6 & $\begin{array}{l}\text { Bouschlicher MR, Reinhardt JW, Vargas MA. Surface treatment techniques for resin composite repair. Am J } \\
\text { Dent 1997;10:279-283. }\end{array}$ \\
\hline 7 & $\begin{array}{l}\text { Lewis G, Johnson W, Martin W, Canerdy A, Claburn C, Collier M. Shear bond strength of immediately } \\
\text { repaired light-cured composite resin restorations. Oper Dent 1998;23:121-127. }\end{array}$ \\
\hline 8 & $\begin{array}{l}\text { Shahdad SA, Kennedy JG. Bond strength of repaired anterior composite resins: an in vitro study. J Dent } \\
1998 ; 26: 685-694 \text {. }\end{array}$ \\
\hline 9 & $\begin{array}{l}\text { Sau CW, Oh GS, Koh H, Chee CS, Lim CC. Shear bond strength of repaired composite resins using a hybrid } \\
\text { composite resin. Oper Dent 1999;24:156-161. }\end{array}$ \\
\hline 10 & $\begin{array}{l}\text { Yap AU, Sau CW, Lye KW. Effects of aging on repair bond strengths of a polyacid-modified composite resin. } \\
\text { Oper Dent } 1999 ; 24: 371-376 \text {. }\end{array}$ \\
\hline 11 & $\begin{array}{l}\text { Kallio TT, Lastumäki TM, Vallittu PK. Bonding of restorative and veneering composite resin to some polymeric } \\
\text { composites. Dent Mater } 2001 ; 17: 80-86 \text {. }\end{array}$ \\
\hline 12 & $\begin{array}{l}\text { Lucena-Martín C, González-López S, Navajas-Rodríguez de Mondelo JM. The effect of various surface } \\
\text { treatments and bonding agents on the repaired strength of heat-treated composites. J Prosthet Dent } \\
2001 ; 86: 481-488 \text {. }\end{array}$ \\
\hline 13 & $\begin{array}{l}\text { Hisamatsu } N \text {, Atsuta } M \text {, Matsumura } \mathrm{H} \text {. Effect of silane primers and unfilled resin bonding agents on repair } \\
\text { bond strength of a prosthodontic microfilled composite. J Oral Rehabil 2002;29:644-648. }\end{array}$ \\
\hline 14 & $\begin{array}{l}\text { Frankenberger R, Krämer N, Ebert J, Lohbauer U, Käppel S, ten Weges S, Petschelt A. Fatigue behavior of } \\
\text { the resin-resin bond of partially replaced resin-based composite restorations. Am J Dent 2003;16:17-22. }\end{array}$ \\
\hline 15 & $\begin{array}{l}\text { Oztas N, Alacam A, Bardakçi Y. The effect of air abrasion with two new bonding agents on composite repair. } \\
\text { Oper Dent 2003;28:149-154. }\end{array}$ \\
\hline 16 & $\begin{array}{l}\text { Tezvergil A, Lassila LV, Vallittu PK. Composite-composite repair bond strength: effect of different adhesion } \\
\text { primers. J Dent 2003;31:521-525. }\end{array}$ \\
\hline 17 & $\begin{array}{l}\text { Tezvergil A, Lassila LV, Yli-Urpo A, Vallittu PK. Repair bond strength of restorative resin composite applied to } \\
\text { fiber-reinforced composite substrate. Acta Odontol Scand 2004;62:51-60. }\end{array}$ \\
\hline 18 & $\begin{array}{l}\text { Trajtenberg CP, Powers JM. Effect of hydrofluoric acid on repair bond strength of a laboratory composite. Am } \\
\text { J Dent 2004;17:173-176. }\end{array}$ \\
\hline 19 & atsu N, Ta \\
\hline
\end{tabular}




\begin{tabular}{|c|c|}
\hline & layers of a highly loaded indirect composite. Dent Mater J 2005;24:440-446. \\
\hline 20 & $\begin{array}{l}\text { Özcan M, Alander P, Vallittu PK, Huysmans MC, Kalk W. Effect of three surface conditioning methods to } \\
\text { improve bond strength of particulate filler resin composites. J Mater Sci Mater Med 2005;16:21-27. }\end{array}$ \\
\hline 21 & $\begin{array}{l}\text { Teixeira EC, Bayne SC, Thompson JY, Ritter AV, Swift EJ. Shear bond strength of self-etching bonding } \\
\text { systems in combination with various composites used for repairing aged composites. J Adhes Dent } \\
2005 ; 7: 159-164 \text {. }\end{array}$ \\
\hline 22 & $\begin{array}{l}\text { Hannig C, Laubach S, Hahn P, Attin T. Shear bond strength of repaired adhesive filling materials using } \\
\text { different repair procedures. J Adhes Dent 2006;8:35-40. }\end{array}$ \\
\hline 23 & $\begin{array}{l}\text { Brendeke J, Özcan M. Effect of physicochemical aging conditions on the composite-composite repair bond } \\
\text { strength. J Adhes Dent 2007;9:399-406. }\end{array}$ \\
\hline 24 & $\begin{array}{l}\text { Dall'Oca S, Papacchini F, Goracci C, Cury AH, Suh BI, Tay FR, Polimeni A, Ferrari M. Effect of oxygen } \\
\text { inhibition on composite repair strength over time. J Biomed Mater Res B Appl Biomater 2007;81:493-498. }\end{array}$ \\
\hline 25 & $\begin{array}{l}\text { Lassila LV, Tezvergil A, Dyer SR, Vallittu PK. The bond strength of particulate-filler composite to differently } \\
\text { oriented fiber-reinforced composite substrate. J Prosthodont } 2007 ; 16: 10-17 \text {. }\end{array}$ \\
\hline 26 & $\begin{array}{l}\text { Özcan M, Barbosa SH, Melo RM, Galhano GA, Bottino MA. Effect of surface conditioning methods on the } \\
\text { microtensile bond strength of resin composite to composite after aging conditions. Dent Mater 2007;23:1276- } \\
1282 \text {. }\end{array}$ \\
\hline 27 & $\begin{array}{l}\text { Papacchini F, Dall'Oca S, Chieffi N, Goracci C, Sadek FT, Suh BI, Tay FR, Ferrari M. Composite-to- } \\
\text { composite microtensile bond strength in the repair of a microfilled hybrid resin: effect of surface treatment and } \\
\text { oxygen inhibition. J Adhes Dent } 2007 ; 9: 25-31 \text {. }\end{array}$ \\
\hline 28 & $\begin{array}{l}\text { Papacchini F, Monticelli F, Hasa I, Radovic I, Fabianelli A, Polimeni A, Ferrari M. Effect of air-drying } \\
\text { temperature on the effectiveness of silane primers and coupling blends in the repair of a microhybrid resin } \\
\text { composite. J Adhes Dent 2007;9:391-397. }\end{array}$ \\
\hline 29 & $\begin{array}{l}\text { Papacchini F, Monticelli F, Radovic I, Chieffi N, Goracci C, Tay FR, Polimeni A, Ferrari M. The application of } \\
\text { hydrogen peroxide in composite repair. J Biomed Mater Res B Appl Biomater 2007;82:298-304. }\end{array}$ \\
\hline 30 & $\begin{array}{l}\text { Papacchini F, Toledano M, Monticelli F, Osorio R, Radovic I, Polimeni A, García-Godoy F, Ferrari M. } \\
\text { Hydrolytic stability of composite repair bond. Eur J Oral Sci 2007;115:417-424. }\end{array}$ \\
\hline 31 & $\begin{array}{l}\text { Chen HL, Lai YL, Chou IC, Hu CJ, Lee SY. Shear bond strength of provisional restoration materials repaired } \\
\text { with light-cured resins. Oper Dent 2008;33:508-515. }\end{array}$ \\
\hline 32 & $\begin{array}{l}\text { Dall'oca S, Papacchini F, Radovic I, Polimeni A, Ferrari M. Repair potential of a laboratory-processed nano- } \\
\text { hybrid resin composite. J Oral Sci 2008;50:403-412. }\end{array}$ \\
\hline 33 & $\begin{array}{l}\text { Fawzy AS, El-Askary FS, Amer MA. Effect of surface treatments on the tensile bond strength of repaired } \\
\text { water-aged anterior restorative micro-fine hybrid resin composite. J Dent } 2008 ; 36: 969-976 \text {. }\end{array}$ \\
\hline 34 & $\begin{array}{l}\text { Papacchini F, Radovic I, Magni E, Goracci C, Monticelli F, Chieffi N, Polimeni A, Ferrari M. Flowable } \\
\text { composites as intermediate agents without adhesive application in resin composite repair. Am J Dent } \\
2008 ; 21: 53-58 \text {. }\end{array}$ \\
\hline 35 & $\begin{array}{l}\text { Souza EM, Francischone CE, Powers JM, Rached RN, Vieira S. Effect of different surface treatments on the } \\
\text { repair bond strength of indirect composites. Am J Dent 2008;21:93-96. }\end{array}$ \\
\hline 36 & $\begin{array}{l}\text { El-Askary FS, Fawzy AS, Abd Elmohsen HM. Tensile bond strength of immediately repaired anterior microfine } \\
\text { hybrid restorative composite using nontrimmed hourglass specimens. J Adhes Dent 2009;11:41-47. }\end{array}$ \\
\hline 37 & Perriard J, Lorente MC, Scherrer S, Belser UC, Wiskott HW. The \\
\hline
\end{tabular}




\begin{tabular}{|l|l}
\hline & $\begin{array}{l}\text { contaminants on the bond strength and interfacial polymerization of a nanohybrid composite. J Adhes Dent } \\
2009 ; 11: 469-478 .\end{array}$ \\
\hline 38 & $\begin{array}{l}\text { Vivas J, Yaman P, Taylor G. Effect of different surface treatments on the shear and flexural re-bond strengths } \\
\text { of a micro-hybrid composite. J Contemp Dent Pract 2009;10:E001-8. }\end{array}$ \\
\hline 39 & $\begin{array}{l}\text { Yesilyurt C, Kusgoz A, Bayram M, Ulker M. Initial repair bond strength of a nano-filled hybrid resin: effect of } \\
\text { surface treatments and bonding agents. J Esthet Restor Dent 2009;21:251-260. }\end{array}$ \\
\hline 40 & $\begin{array}{l}\text { Costa TR, Ferreira SQ, Klein-Júnior CA, Loguercio AD, Reis A. Durability of surface treatments and } \\
\text { intermediate agents used for repair of a polished composite. Oper Dent 2010;35:231-237. }\end{array}$ \\
\hline 41 & $\begin{array}{l}\text { Rinastiti M, Özcan M, Siswomihardjo W, Busscher HJ. Immediate repair bond strengths of microhybrid, } \\
\text { nanohybrid and nanofilled composites after different surface treatments. J Dent 2010;38:29-38. }\end{array}$ \\
\hline
\end{tabular}


Table 3. Sequence of surface conditioning methods used for composite resins as stated by the authors.

\section{Surface Conditioning Methods}

$14 \mathrm{~d}$ air aging+Grinding 400grit

Abraded Sof-Lex disk

Abraded with diamond fissure bar

Abraded with diamond fissure bar+Bonding

Abrasion corse $\mathrm{Al} 2 \mathrm{O} 3$ disk+cleaning with $37 \% \mathrm{H} 3 \mathrm{PO} 4$ (60s)+Bonding

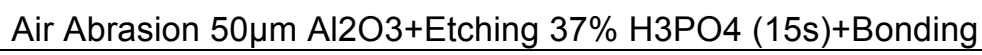

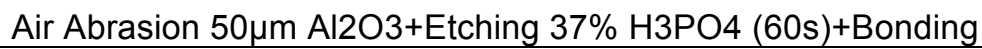

Air-abraded 50 $\mu \mathrm{m} \mathrm{Al} 2 \mathrm{O} 3+$ Etching 35\% PA (30s)+Bonding

Air-inhibition

Air-steam+50 $\mu \mathrm{m} \mathrm{Al2O3+Bonding}$

Air-steam+50 $\mu \mathrm{m} \mathrm{Al2O3+Silanization+Bonding}$

Bonding

Cleaning 37\% H3PO4 (30s)+Bonding

CoJet $30 \mu \mathrm{m}$ SiOx+Silanization

Cojet Silica coating 30 $\mu \mathrm{m}$ Al2O3+Etching 37\% H3PO4 (30s)+Bonding

Co-Jet+Silanization

Diamond Bur $150 \mu \mathrm{m}+$ Bonding

Diamond bur fine grit+Bonding+light curing in air-atmosphere

Diamond bur fine grit+Bonding+light curing in nitrogen-atmosphere

Diamond bur fine grit+Etching 37\% H3PO4(30s)+Bonding+light curing in air-atmosphere

Diamond bur fine grit+Etching 37\% $\mathrm{H} 3 \mathrm{PO} 4(30 \mathrm{~s})+$ Bonding+light curing in nitrogen-atmosphere

Diamond bur medium grit+Cleaning 37\% H3PO4 (30s)+Bonding

Etching $>10 \% \mathrm{HCL} \& 6.9 \% \mathrm{HF}(60 \mathrm{~s})+$ Bonding+light curing in air-atmosphere

Etching $>10 \% \mathrm{HCL} \& 6.9 \% \mathrm{HF}(60 \mathrm{~s})+$ Bonding+light curing in nitrogen-atmosphere

Etching 35\% PA (30s)+Bonding

Etching 37\% H3PO4 (15s)+9.6\% HF (120s)+Bonding

Etching 37\% H3PO4 (15s)+99\% acetone (60s)+Bonding

Etching 37\% H3PO4 (15s)+Bonding

Etching 37\% H3PO4 (15s)+Silanization+Bonding

Etching 37\% H3PO4 (15s)+with polyester strip+Bonding

Etching 37\% H3PO4 (30s)+Bonding

Etching 37\% H3PO4 (60s)+Bonding

Etching $37 \%$ PA (5min)

Etching 38\% $\mathrm{H} 2 \mathrm{O} 2+$ Bonding

Etching 38\% H2O2+Silanization+Bonding

Etching 38\% PA (60s)+Bonding

Etching 9.5\% Hydrophloric Acid (60s)

Etching 9.5\% Hydrophloric Acid (60s)+Bonding

Etching 9.5\% Hydrophloric Acid (60s)+Silanisation

Etching 9.6\% HF (120s)+Bonding

Etching $9.6 \% \mathrm{HF}(60 \mathrm{~s})+$ Bonding 
Finishing Diamond bur 40grit+cleaning in ethanol 10s

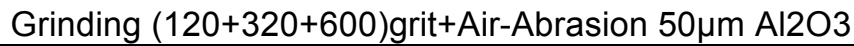

Grinding $(120+320+600)$ grit+Etching $8 \% \mathrm{HF}(15 \mathrm{~s})+$ immersion $\mathrm{NaOH}(5 \mathrm{~min})+$ Silanization+Bonding

Grinding $(120+320+600)$ grit+Etching $8 \% \mathrm{HF}(15 \mathrm{~s})+$ Silanization+Bonding

Grinding $(60+120+320+600)$ grit+Etching $5 \%$ HF (10s)

Grinding $(60+120+320+600)$ grit+Etching $5 \% \mathrm{HF}(15 \mathrm{~s})$

Grinding $(60+120+320+600)$ grit+Etching $5 \%$ HF (30s)

Grinding $(60+120+320+600)$ grit+Etching $5 \% \mathrm{HF}(5 \mathrm{~s})$

Grinding $(60+120+320+600)$ grit+Etching $5 \% \mathrm{HF}(60 \mathrm{~s})$

Grinding $(60+120+320+600)$ grit+Etching $8 \% \mathrm{HF}(10 \mathrm{~s})$

Grinding $(60+120+320+600)$ grit+Etching $8 \% \mathrm{HF}(15 \mathrm{~s})$

Grinding $(60+120+320+600)$ grit+Etching $8 \% \mathrm{HF}(30 \mathrm{~s})$

Grinding $(60+120+320+600)$ grit+Etching $8 \% \mathrm{HF}(5 \mathrm{~s})$

Grinding $(60+120+320+600)$ grit+Etching $8 \% \mathrm{HF}(60 \mathrm{~s})$

Grinding $(60+120+320+600)$ grit+Etching $9.5 \% \mathrm{HF}(10 \mathrm{~s})$

Grinding $(60+120+320+600)$ grit+Etching $9.5 \% \mathrm{HF}(15 \mathrm{~s})$

Grinding $(60+120+320+600)$ grit+Etching $9.5 \% \mathrm{HF}(30 \mathrm{~s})$

Grinding $(60+120+320+600)$ grit+Etching $9.5 \% \mathrm{HF}(5 \mathrm{~s})$

Grinding $(60+120+320+600)$ grit+Etching $9.5 \% \mathrm{HF}(60 \mathrm{~s})$

Grinding 1200grit+Bonding

Grinding 1200grit+US cleaning in distilled water (10 min)+Air-borne Abrasion 50 $\mu$ m Al2O3+Silanization+Bonding

Grinding 1200grit+US cleaning in distilled water $(10 \mathrm{~min})+$ Cojet Silica coating $30 \mu \mathrm{m}$ SiO2+Silanization

Grinding 1200grit+US cleaning in distilled water $(10 \mathrm{~min})+$ Cojet Silica coating $30 \mu \mathrm{m}$ SiO2+Silanization+Bonding

Grinding 1200grit+US cleaning in distilled water (10min)+Etching 35\% H3PO4(60s)+Bonding

Grinding 1200grit+US cleaning in distilled water (10 min)+Etching 9.5\% HF (90s)+Silanization+Bonding

Grinding 1200grit+US cleaning in distilled water (15min)

Grinding 1200grit+US cleaning in distilled water (15min)+Bonding

Grinding 180grit+US cleaning in distilled water

Grinding 180grit+US cleaning in distilled water+Bonding

Grinding 320grit

Grinding 320grit+Etching (10\% maleic acid 20s)+Bonding

Grinding 320grit+Etching (10\% polyacrylic acid 20 s)+Bonding

Grinding 320grit+Sandblasting 50 $\mu \mathrm{m} \mathrm{Al2O3+Bonding}$

Grinding 400grit

Grinding 400grit+Bonding

Grinding 400grit+dipped in blood 15s

Grinding 400grit+dipped in fresh saliva $15 \mathrm{~s}$

Grinding 400grit+Grinding 240grit+Bonding

Grinding 400grit+Silanization

Grinding 400grit+Silanization+Bonding

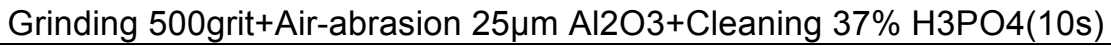

Grinding 500grit+Air-abrasion 25 $\mu \mathrm{m} \mathrm{Al} 2 \mathrm{O} 3+$ Cleaning 37\% H3PO4(10s)+Bonding

Grinding 500grit+Sanded+500grit Al2O3+Cleaning 37\% H3PO4(10s)

Grinding 500grit+Sanded+500grit Al2O3+Cleaning 37\% H3PO4(10s)+Bonding 
Grinding 5x (150grit+360grit+600grit+1200grit)+Bonding

Grinding 5x(150grit+360grit+600grit+1200grit)+Diamond bur+Cleaning 35\% H3PO4 (30s)+Bonding

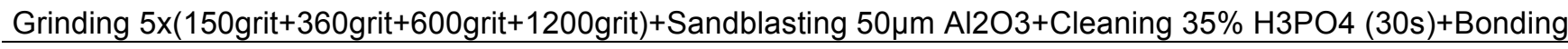

Grinding 600grit Soflex Disk+Etching 35\% H3PO4(15s)+Bonding

Grinding 600grit+Bonding

Grinding 800grit+Etching H3PO4 (60s)+Bonding

Grinding 800grit+Etching H3PO4 (60s)+Co-Jet+Silanization

Grinding 800grit+Etching H3PO4 (60s)+Co-Jet+Silanization+Bonding

Grinding 800grit+Etching H3PO4 (60s)+Silanization

Grinding 800grit+Etching H3PO4 (60s)+Silanization+Bonding

Grinding abrasive stone+Bonding

Grinding abrasive stone+Etching 37\% H3PO4 (15s)+Bonding

Grinding abrasive stone+Etching 37\% H3PO4 (15s)+with polyester strip+Bonding

Grinding abrasive stone+Silanization+Bonding

Grinding abrasive stone+Silanization+Etching 37\% H3PO4 (15s)+Bonding

Grinding abrasive stone+with polyester strip+Bonding

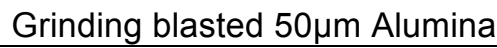

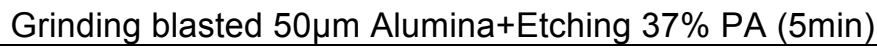

Grinding diamondstone

Grinding diamondstone+Bonding

Grinding diamondstone+Silanisation

Grinding fluted carbide bur

Grinding Green Carborundum stone

Grinding Green Carborundum stone+Bonding

Grinding Green Carborundum stone+Silanisation

Hand-polished 320grit silicon carbide+US cleaning 3min+abraded 4s with 27 $\mu \mathrm{m} \mathrm{Al2O}$ (KCP-2000)+32\% H3PO4 15s

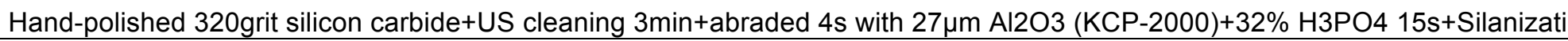

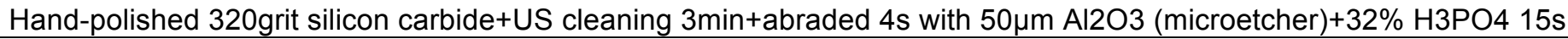

Hand-polished 320grit silicon carbide+US cleaning 3min+abraded 4s with 50 $\mathrm{mm}$ Al2O3 (microetcher)+32\% H3PO4 15s+Silaniza

Hand-polished 320grit silicon carbide+US cleaning 3min+abraded 4s with Cojet Sand

Hand-polished 320grit silicon carbide+US cleaning 3min+abraded 4s with Cojet Sand+Silanization

Hand-polished 320grit silicon carbide+US cleaning 3min+roughened 4s with fine grit diamond bur+32\% H3PO4 15s

Hand-polished 320grit silicon carbide+US cleaning 3min+roughened 4s with fine grit diamond bur+32\% H3PO4 15s+Silanizatior Jet prophylaxis+Sodium bicarbonate

Jet prophylaxis+Sodium bicarbonate+Bonding

Jet prophylaxis+Sodium bicarbonate+Silanisation

No treatment

No treatment+abraded with polyester strip

No treatment+abraded without polyester strip

Non air-inhibition+Mylar Strip

Polishing 600grit+Bonding

Polymerization against Mylar Strip+Bonding

Polyester strip+Bonding

Polymerization against Mylar Strip+No treatment 
Polymerization against Mylar Strip+Silicacoating 30 $\mu \mathrm{m}$ Alumina+Silanization+Bonding

Received two $1 \mathrm{~mm}$ deep grooves+Etching 35\% PA (30s)+Bonding

Rinsed with warm water+brushed with toothbrush $20 x$

Rinsed with warm water+brushed with toothbrush $20 x+99 \%$ acetone

Rinsed with warm water+brushed with toothbrush $20 x+$ bracket primer

Rinsed with warm water+brushed with toothbrush $20 x+$ catalyst resin

Rinsed with warm water+brushed with toothbrush $20 x+$ roughening with green stone bur

Rinsed with warm water+brushed with toothbrush $20 x+$ universal resin

Sandblasting $50 \mu \mathrm{m} \mathrm{Al}_{2} \mathrm{O}_{3}$

Sandblasting $50 \mu \mathrm{m} \mathrm{Al}_{2} \mathrm{O}_{3}+$ Bonding

Sandblasting $50 \mu \mathrm{m} \mathrm{Al}_{2} \mathrm{O}_{3}+$ Cleaning $35 \% \mathrm{H} 3 \mathrm{PO} 4(30 \mathrm{~s})$

Sandblasting $50 \mu \mathrm{m} \mathrm{Al}_{2} \mathrm{O}_{3}+$ Cleaning $35 \% \mathrm{H} 3 \mathrm{PO} 4(30 \mathrm{~s})+$ Bonding

Sandblasting 50 $\mu \mathrm{m} \mathrm{Al}_{2} \mathrm{O}_{3}+$ Cleaning 35\% $\mathrm{H} 3 \mathrm{PO} 4(30 \mathrm{~s})+$ Silanization

Sandblasting $50 \mu \mathrm{m} \mathrm{Al}_{2} \mathrm{O}_{3}+$ Cleaning 35\% $\mathrm{H} 3 \mathrm{PO} 4(30$ s)+Silanization+Bonding

Sandblasting $50 \mu \mathrm{m} \mathrm{Al}_{2} \mathrm{O}_{3}+$ Cleaning $37 \% \mathrm{H} 3 \mathrm{PO} 4$ (30s)+Bonding

Sandblasting $50 \mu \mathrm{m} \mathrm{Al}_{2} \mathrm{O}_{3}+$ Etching $35 \% \mathrm{H} 3 \mathrm{PO} 4(30 \mathrm{~s})+$ Silanisation+air syringe $23^{\circ} \mathrm{C}$

Sandblasting $50 \mu \mathrm{m} \mathrm{Al}_{2} \mathrm{O}_{3}+$ Etching $35 \% \mathrm{H} 3 \mathrm{PO} 4(30 \mathrm{~s})+$ Silanisation+blowdrier $38^{\circ} \mathrm{C}$

Sandblasting $50 \mu \mathrm{m} \mathrm{Al}_{2} \mathrm{O}_{3}+$ Etching $35 \% \mathrm{H} 3 \mathrm{PO} 4(30 \mathrm{~s})+$ Silanisation+Bonding+air syringe $23^{\circ} \mathrm{C}$

Sandblasting $50 \mu \mathrm{m} \mathrm{Al}_{2} \mathrm{O}_{3}+$ Etching $35 \% \mathrm{H} 3 \mathrm{PO} 4(30 \mathrm{~s})+$ Silanisation+Bonding+blowdrier $38^{\circ} \mathrm{C}$

Sandblasting 50 $\mathrm{mm} \mathrm{Al}_{2} \mathrm{O}_{3}$ +Etching 37\% $\mathrm{H} 3 \mathrm{PO} 4(30 \mathrm{~s})+$ Bonding+light curing in air-atmosphere

Sandblasting $50 \mu \mathrm{m} \mathrm{Al}_{2} \mathrm{O}_{3}+$ Etching $37 \% \mathrm{H}_{3} \mathrm{PO} 4(30 \mathrm{~s})+$ Bonding+light curing in nitrogen-atmosphere

Sandblasting $50 \mu \mathrm{m} \mathrm{Al}_{2} \mathrm{O}_{3}+$ Silanisation

Sandblasting SB particles (15s)+Bonding

Silanization+Bonding

Silicon Carbide bur 140grit

Silicon Carbide bur 140grit+Bonding

Wet-grinding 1200grit+Bonding

Wet-grinding 1200grit+CoJet Sand+Silanization+Bonding

Wet-grinding 1200grit+Silanization+Bonding

Wet-grinding 320grit

Wet-grinding 320grit+Bonding 
Table 4 Descriptive statistics on the different parameters tabulated from the selected studies according to the surfac conditioning method, aging conditions for the substrate and the test method.

\begin{tabular}{|ll|l|r|r|}
\hline & & Value Label & $\begin{array}{c}\text { N } \\
\text { (Substrate= } \\
\text { Adherent) }\end{array}$ & $\begin{array}{c}\text { N } \\
\text { (Substrate } \neq \text { Adherent) }\end{array}$ \\
\hline \multirow{4}{*}{ Surface } & 0 & Control & 28 & 2 \\
Conditioning & 1 & Physical & 19 & 13 \\
& 2 & Chemical & 45 & 16 \\
& 3 & Physicochemical & 225 & 101 \\
& 1 & Macroshear & 213 & 87 \\
Test Method & 2 & Macrotensile & 6 & 39 \\
& 3 & Microtensile & 98 & 6 \\
\hline \multirow{2}{*}{ Thermocycling } & 0 & No & 257 & 108 \\
& 1 & Yes & 60 & 24 \\
\hline
\end{tabular}

\begin{tabular}{|c|c|c|c|c|}
\hline & & Value Label & $\begin{array}{c}\mathrm{N} \\
\text { (Substrate= } \\
\text { Adherent) }\end{array}$ & $\stackrel{\mathrm{N}}{\text { (Substrate } \neq \text { Adherent) }}$ \\
\hline \multirow{4}{*}{$\begin{array}{l}\text { Surface } \\
\text { Conditioning }\end{array}$} & 0 & Control & 28 & 2 \\
\hline & 1 & Physical & 19 & 13 \\
\hline & 2 & Chemical & 45 & 16 \\
\hline & 3 & Physicochemical & 225 & 101 \\
\hline \multirow{3}{*}{ Test Method } & 1 & Macroshear & 213 & 87 \\
\hline & 2 & Macrotensile & 6 & 39 \\
\hline & 3 & Microtensile & 98 & 6 \\
\hline \multirow{2}{*}{$\begin{array}{l}\text { Water Storage } \\
\text { of the } \\
\text { substrate }\end{array}$} & 0 & No & 129 & 8 \\
\hline & 1 & Yes & 188 & 124 \\
\hline
\end{tabular}


Tables 5a-b Significant effects of surface conditioning methods, test methods and their interactions on mean bond strengths for thermocycled groups for substrate-adherent type of a) being of the same kind (Substrate=Adherent) or b) dissimilar (Substrate $\neq$ Adherent).

\section{Table 5a}

Tests of Between-Subjects Effects ${ }^{\mathrm{b}, \mathrm{c}}$

Dependent Variable: Mean Bond Strength (MPa)

\begin{tabular}{|l|l|l|l|l|l|}
\hline Source & $\begin{array}{l}\text { Type III Sum } \\
\text { of Squares }\end{array}$ & df & $\begin{array}{l}\text { Mean } \\
\text { Square }\end{array}$ & F & Significance \\
\hline Corrected Model & $34170.699^{\mathrm{a}}$ & 13 & 2628.515 & 10.640 & .000 \\
Intercept & 22302.025 & 1 & 22302.025 & 90.276 & .000 \\
Surface Conditioning & 2871.745 & 3 & 957.248 & 3.875 & .010 \\
Test method & 2130.357 & 2 & 1065.178 & 4.312 & .014 \\
Thermocycling & 276.490 & 1 & 276.490 & 1.119 & .291 \\
Surface Conditioning * Test method & 862.431 & 3 & 287.477 & 1.164 & .324 \\
Surface Conditioning * & 761.588 & 3 & 253.863 & 1.028 & .381 \\
Thermocycling & 3016.073 & 1 & 3016.073 & 12.209 & .001 \\
Test method * Thermocycling & & & & & \\
Surface Conditioning * Test method & .000 & 0 &. & & \\
* Thermocycling & & & & & \\
Error & & & & & \\
Total & & & & & \\
Corrected Total & 74853.616 & 303 & 247.042 & & \\
\hline
\end{tabular}

a. $\mathrm{R}$ Squared $=.313$ (Adjusted $\mathrm{R}$ Squared $=.284$ )

b. Substrate=Adherent

c. Weighted Least Squares Regression - Weighted by Weight 
Table 5b

Tests of Between-Subjects Effects ${ }^{\mathrm{b}, \mathrm{c}}$

Dependent Variable: Mean Bond Strength (MPa)

\begin{tabular}{|l|l|l|l|l|l|}
\hline Source & $\begin{array}{l}\text { Type III Sum } \\
\text { of Squares }\end{array}$ & df & Mean Square & F & Sig. \\
\hline Corrected Model & $13746.134^{\mathrm{a}}$ & 11 & 1249.649 & 5.941 & .000 \\
Intercept & 14967.681 & 1 & 14967.681 & 71.153 & .000 \\
Surface Conditioning & 15.216 & 3 & 5.072 & .024 & .995 \\
Test method & 7638.742 & 2 & 3819.371 & 18.156 & .000 \\
Thermocycling & 326.111 & 1 & 326.111 & 1.550 & .216 \\
Surface Conditioning * Test & 2883.175 & 2 & 1441.588 & 6.853 & .002 \\
method & 34.050 & 3 & 11.350 & .054 & .983 \\
Surface Conditioning * & & & & & \\
Thermocycling & .000 & 0 &. &. &. \\
Test method * Thermocycling & .000 & 0 &. & & \\
Surface Conditioning * Test & & & & & \\
method * Thermocycling & 25243.258 & 120 & 210.360 & & \\
Error & 220211.992 & 132 & & & \\
Total & 38989.392 & 131 & & & \\
Corrected Total & & & & & \\
\hline
\end{tabular}

a. $\mathrm{R}$ Squared $=.353$ (Adjusted R Squared $=.293$ )

b. Substrate $\neq$ Adherent

c. Weighted Least Squares Regression - Weighted by Weight 
Tables 6a-b Significant differences for cross-comparisons and interactions between surface conditioning methods, test methods for thermocycled groups for substrate-adherent type of a) being of the same kind (Substrate=Adherent) or b) dissimilar (Substrate $\neq$ Adherent).

Table 6a

\section{Parameter Estimates ${ }^{\mathrm{b}, \mathrm{c}}$}

Dependent Variable: Mean Bond Strength (MPa)

\begin{tabular}{|c|c|c|c|c|c|c|}
\hline \multirow[b]{2}{*}{ Parameter } & \multirow[b]{2}{*}{ B } & \multirow[b]{2}{*}{$\begin{array}{l}\text { Std. } \\
\text { Error }\end{array}$} & \multirow[b]{2}{*}{$t$} & \multirow[b]{2}{*}{ Sig. } & \multicolumn{2}{|c|}{$95 \%$ Confidence Interval } \\
\hline & & & & & $\begin{array}{l}\text { Lower } \\
\text { Bound } \\
\end{array}$ & $\begin{array}{l}\text { Upper } \\
\text { Bound } \\
\end{array}$ \\
\hline Intercept & 36.627 & 2.871 & 12.756 & .000 & 30.977 & 42.277 \\
\hline [Surface Conditioning=0] & -19.670 & 12.892 & -1.526 & .128 & -45.038 & 5.699 \\
\hline [Surface Conditioning=1] & 5.382 & 15.241 & .353 & .724 & -24.609 & 35.373 \\
\hline [Surface Conditioning=2] & -.481 & 10.117 & -.048 & .962 & -20.390 & 19.429 \\
\hline [Surface Conditioning=3] & $0^{a}$ & - & - & - & - & - \\
\hline [Test method=1] & -18.378 & 3.800 & -4.836 & .000 & -25.857 & -10.899 \\
\hline [Test method=2] & -16.380 & 7.295 & -2.245 & .025 & -30.736 & -2.025 \\
\hline [Test method $=3$ ] & $0^{\mathrm{a}}$ & - & - & - & - & - \\
\hline$[$ Thermocycling $=0]$ & .820 & 3.063 & .268 & .789 & -5.207 & 6.847 \\
\hline [Thermocycling $=1]$ & $0^{\mathrm{a}}$ & - & - & - & - & - \\
\hline $\begin{array}{l}{[\text { Surface Conditioning }=0] *[\text { Test }} \\
\text { method }=1]\end{array}$ & 13.833 & 9.055 & 1.528 & .128 & -3.986 & 31.651 \\
\hline $\begin{array}{l}{[\text { Surface Conditioning }=1] \text { * }[\text { Test }} \\
\operatorname{method}=1]\end{array}$ & -6.145 & 11.456 & -.536 & .592 & -28.688 & 16.397 \\
\hline $\begin{array}{l}{[\text { Surface Conditioning }=2] *[\text { Test }} \\
\operatorname{method}=1]\end{array}$ & -3.586 & 4.286 & -.837 & .403 & -12.020 & 4.847 \\
\hline $\begin{array}{l}{[\text { Surface Conditioning }=0] \text { * }} \\
{[\text { Thermocycling }=0]}\end{array}$ & -5.078 & 9.756 & -.520 & .603 & -24.276 & 14.121 \\
\hline $\begin{array}{l}{[\text { Surface Conditioning }=1] \text { * }} \\
{[\text { Thermocycling }=0]}\end{array}$ & -13.115 & 10.728 & -1.222 & .222 & -34.227 & 7.997 \\
\hline $\begin{array}{l}{[\text { Surface Conditioning }=2] \text { * }} \\
{[\text { Thermocycling }=0]}\end{array}$ & -12.653 & 9.756 & -1.297 & .196 & -31.851 & 6.546 \\
\hline $\begin{array}{l}{[\text { Test method }=1] \text { * }} \\
{[\text { Thermocycling }=0]}\end{array}$ & 14.363 & 4.111 & 3.494 & .001 & 6.274 & 22.452 \\
\hline $\begin{array}{l}{[\text { Test method }=1] \text { * }} \\
{[\text { Thermocycling }=1]}\end{array}$ & $0^{a}$ & - & - & - & - & - \\
\hline
\end{tabular}

a. This parameter is set to zero because it is redundant.

b. Substrate=Adherent

c. Weighted Least Squares Regression - Weighted by Weight 
Table 6b

Parameter Estimates ${ }^{\mathrm{b}, \mathrm{c}}$

Dependent Variable: Mean Bond Strength (MPa)

\begin{tabular}{|c|c|c|c|c|c|c|}
\hline \multirow[b]{2}{*}{ Parameter } & \multirow[b]{2}{*}{ B } & \multirow[b]{2}{*}{$\begin{array}{l}\text { Std. } \\
\text { Error }\end{array}$} & \multirow[b]{2}{*}{$\mathrm{t}$} & \multirow[b]{2}{*}{ Sig. } & \multicolumn{2}{|c|}{$\begin{array}{c}95 \% \text { Confidence } \\
\text { Interval }\end{array}$} \\
\hline & & & & & $\begin{array}{l}\text { Lower } \\
\text { Bound }\end{array}$ & $\begin{array}{l}\text { Upper } \\
\text { Bound }\end{array}$ \\
\hline Intercept & 27.003 & 5.145 & 5.248 & .000 & 16.816 & 37.190 \\
\hline [Surface Conditioning=0] & 10.426 & 22.003 & -.474 & .636 & -53.990 & 33.138 \\
\hline [Surface Conditioning=1] & 11.127 & 16.372 & .680 & .498 & -21.289 & 43.544 \\
\hline [Surface Conditioning=2] & 14.334 & 11.367 & 1.261 & .210 & -8.172 & 36.840 \\
\hline [Surface Conditioning=3] & $0^{a}$ & - & - & - & - & - \\
\hline [Test method=1] & $\begin{array}{r}- \\
10.577\end{array}$ & 3.567 & -2.965 & .004 & -17.640 & -3.514 \\
\hline [Test method=2] & $\begin{array}{r}- \\
11.830\end{array}$ & 3.607 & -3.280 & .001 & -18.972 & -4.688 \\
\hline [Test method=3] & $0^{a}$ & - & - & - & - & - \\
\hline [Thermocycling $=0$ ] & 10.083 & 4.008 & 2.516 & .013 & 2.148 & 18.018 \\
\hline [Thermocycling=1] & $0^{a}$ & - & - & & - & - \\
\hline $\begin{array}{l}{[\text { Surface Conditioning }=1] *[\text { Test }} \\
\operatorname{method}=1]\end{array}$ & $\begin{array}{r}- \\
20.753\end{array}$ & 8.134 & -2.551 & .012 & -36.858 & -4.649 \\
\hline $\begin{array}{l}{[\text { Surface Conditioning }=1] *[\text { Test }} \\
\text { method }=2]\end{array}$ & $0^{a}$ & - & - & - & - & - \\
\hline $\begin{array}{l}{[\text { Surface Conditioning }=2] *[\text { Test }} \\
\operatorname{method}=1]\end{array}$ & $\begin{array}{r}- \\
22.038\end{array}$ & 7.950 & -2.772 & .006 & -37.778 & -6.298 \\
\hline $\begin{array}{l}{[\text { Surface Conditioning }=2] *[\text { Test }} \\
\text { method }=3]\end{array}$ & $0^{a}$ & - & - & - & - & - \\
\hline $\begin{array}{l}{[\text { Surface Conditioning }=0] \text { * }} \\
{[\text { Thermocycling }=0]}\end{array}$ & 1.917 & 24.032 & .080 & .937 & -45.664 & 49.499 \\
\hline $\begin{array}{l}{[\text { Surface Conditioning }=1] \text { * }} \\
{[\text { Thermocycling }=0]}\end{array}$ & -1.073 & 15.799 & -.068 & .946 & -32.355 & 30.208 \\
\hline $\begin{array}{l}\text { [Surface Conditioning }=2] \text { * } \\
{[\text { Thermocycling }=0]}\end{array}$ & -3.896 & 10.072 & -.387 & .700 & -23.838 & 16.046 \\
\hline
\end{tabular}

a. This parameter is set to zero because it is redundant.

b. Substrate $\neq$ Adherent

c. Weighted Least Squares Regression - Weighted by Weight 
Tables 7a-b Significant effects of surface conditioning methods, test methods and their interactions on mean bond strengths for water stored groups for substrate-adherent type of a) being of the same kind (Substrate=Adherent) or b) dissimilar (Substrate $\neq$ Adherent)

\section{Table 7a}

\section{Tests of Between-Subjects Effects ${ }^{\mathrm{b}, \mathrm{c}}$}

Dependent Variable: Mean Bond Strength (MPa)

\begin{tabular}{|c|c|c|c|c|c|}
\hline Source & $\begin{array}{l}\text { Type III Sum of } \\
\text { Squares }\end{array}$ & df & Mean Square & $\mathrm{F}$ & Sig. \\
\hline Corrected Model & $47749.860^{a}$ & 15 & 3183.324 & 15.638 & .000 \\
\hline Intercept & 23476.509 & 1 & 23476.509 & 115.324 & .000 \\
\hline Surface Conditioning & 5996.095 & 3 & 1998.698 & 9.818 & .000 \\
\hline Test method & 463.494 & 2 & 231.747 & 1.138 & .322 \\
\hline $\begin{array}{l}\text { Water storage of the } \\
\text { substrate }\end{array}$ & .002 & 1 & .002 & .000 & .998 \\
\hline $\begin{array}{l}\text { Surface Conditioning * Test } \\
\text { method }\end{array}$ & 541.298 & 3 & 180.433 & .886 & .448 \\
\hline $\begin{array}{l}\text { Surface Conditioning * } \\
\text { Water storage of the } \\
\text { substrate }\end{array}$ & 853.188 & 3 & 284.396 & 1.397 & .244 \\
\hline $\begin{array}{l}\text { Test method * Water } \\
\text { storage of the substrate }\end{array}$ & 1307.965 & 1 & 1307.965 & 6.425 & .012 \\
\hline $\begin{array}{l}\text { Surface Conditioning * Test } \\
\text { method * Water storage of } \\
\text { the substrate }\end{array}$ & 299.325 & 2 & 149.663 & .735 & .480 \\
\hline Error & 61274.454 & 301 & 203.570 & & \\
\hline Total & 699491.658 & 317 & & & \\
\hline Corrected Total & 109024.315 & 316 & & & \\
\hline
\end{tabular}

a. $\mathrm{R}$ Squared $=.438$ (Adjusted $\mathrm{R}$ Squared $=.410$ )

b. Substrate=Adherent

c. Weighted Least Squares Regression - Weighted by Weight 
Table 7b

Tests of Between-Subjects Effects ${ }^{\mathrm{b}, \mathrm{c}}$

Dependent Variable: Mean Bond Strength (MPa)

\begin{tabular}{|l|l|l|l|l|l|}
\hline Source & $\begin{array}{l}\text { Type III Sum } \\
\text { of Squares }\end{array}$ & df & Mean Square & F & Sig. \\
\hline Corrected Model & $12666.659^{\mathrm{a}}$ & 9 & 1407.407 & 6.523 & .000 \\
Intercept & 10272.430 & 1 & 10272.430 & 47.610 & .000 \\
Surface Conditioning & 33.057 & 3 & 11.019 & .051 & .985 \\
Test method & 10509.180 & 2 & 5254.590 & 24.354 & .000 \\
Water storage of the substrate & 108.842 & 1 & 108.842 & .504 & .479 \\
Surface Conditioning * Test & 3795.896 & 2 & 1897.948 & 8.797 & .000 \\
method & 1.018 & 1 & 1.018 & .005 & .945 \\
Surface Conditioning * Water & & & & & \\
storage of the substrate & .000 & 0 &. &. & \\
Test method * Water storage of & & & & & \\
the substrate & .000 & 0 &. & & \\
Surface Conditioning * Test & & & & & \\
method * Water storage of the & & 122 & 215.760 & & \\
substrate & 26322.733 & 132 & & & \\
Error & 220211.992 & 131 & & & \\
Total & 38989.392 & 131 & & & \\
Corrected Total & & & & & \\
\hline
\end{tabular}

a. $\mathrm{R}$ Squared $=.325$ (Adjusted R Squared $=.275$ )

b. Substrate $\neq$ Adherent

c. Weighted Least Squares Regression - Weighted by Weight 
Tables 8a-b Significant differences for cross-comparisons and interactions between surface conditioning methods, test methods for water stored groups for substrate-adherent type of a) being of the same kind (Substrate=Adherent) or b) dissimilar (Substrate $\neq$ Adherent).

Table 8a

Parameter Estimates $^{\text {b,c }}$

Dependent Variable: Mean Bond Strength (MPa)

\begin{tabular}{|c|c|c|c|c|c|c|}
\hline \multirow[b]{2}{*}{ Parameter } & \multirow[b]{2}{*}{$B$} & \multirow[b]{2}{*}{$\begin{array}{l}\text { Std. } \\
\text { Error }\end{array}$} & \multirow[b]{2}{*}{$t$} & \multirow[b]{2}{*}{ Sig. } & \multicolumn{2}{|c|}{ 95\% Confidence Interval } \\
\hline & & & & & $\begin{array}{l}\text { Lower } \\
\text { Bound }\end{array}$ & $\begin{array}{l}\text { Upper } \\
\text { Bound }\end{array}$ \\
\hline Intercept & 38.191 & .961 & 39.734 & .000 & 36.299 & 40.082 \\
\hline [Surface Conditioning=0] & -22.391 & 10.774 & -2.078 & .039 & -43.593 & -1.189 \\
\hline [Surface Conditioning=1] & -7.733 & 9.827 & -.787 & .432 & -27.071 & 11.604 \\
\hline [Surface Conditioning=2] & -13.221 & 2.476 & -5.340 & .000 & -18.093 & -8.349 \\
\hline [Surface Conditioning=3] & $0^{a}$ & - & - & - & - & - \\
\hline [Test method=1] & -18.048 & 1.737 & -10.388 & .000 & -21.467 & -14.629 \\
\hline [Test method=2] & -17.124 & 6.621 & -2.586 & .010 & -30.154 & -4.094 \\
\hline [Test method=3] & $0^{\mathrm{a}}$ & - & - & - & - & - \\
\hline [Subtrate aging=0] & -7.734 & 2.911 & -2.656 & .008 & -13.463 & -2.005 \\
\hline [Subtrate aging=1] & $0^{a}$ & - & - & - & - & - \\
\hline $\begin{array}{l}\text { [Surface Conditioning }=0] \text { * } \\
{[\text { Test method }=1]}\end{array}$ & 20.954 & 12.090 & 1.733 & .084 & -2.838 & 44.745 \\
\hline $\begin{array}{l}\text { [Surface Conditioning }=1] \text { * } \\
{[\text { Test method }=1]}\end{array}$ & 4.884 & 10.493 & .465 & .642 & -15.766 & 25.534 \\
\hline $\begin{array}{l}\text { [Surface Conditioning=2] * } \\
{[\text { Test method=1] }}\end{array}$ & 9.007 & 4.418 & 2.039 & .042 & .313 & 17.702 \\
\hline $\begin{array}{l}\text { [Surface Conditioning=2] * } \\
{[\text { Test method }=3]}\end{array}$ & $0^{a}$ & - & - & - & - & - \\
\hline $\begin{array}{l}\text { [Surface Conditioning }=0 \text { ] } \\
{[\text { Water storage of the }} \\
\text { substrate }=0 \text { ] }\end{array}$ & 1.534 & 15.453 & .099 & .921 & -28.875 & 31.943 \\
\hline $\begin{array}{l}\text { [Surface Conditioning }=1] \text { * } \\
\text { [Water storage of the } \\
\text { substrate }=0 \text { ] }\end{array}$ & -8.106 & 7.943 & -1.020 & .308 & -23.738 & 7.526 \\
\hline $\begin{array}{l}\text { [Surface Conditioning }=2 \text { ] * } \\
\text { [Water storage of the } \\
\text { substrate }=0 \text { ] }\end{array}$ & -7.436 & 11.351 & -.655 & .513 & -29.772 & 14.901 \\
\hline $\begin{array}{l}{[\text { Test method }=1]{ }^{*}[\text { Water }} \\
\text { storage of the substrate }=0]\end{array}$ & 26.296 & 3.483 & 7.549 & .000 & 19.441 & 33.151 \\
\hline $\begin{array}{l}{[\text { Test method }=1]{ }^{*}[\text { Water }} \\
\text { storage of the substrate }=1]\end{array}$ & $0^{a}$ & - & - & - & - & - \\
\hline
\end{tabular}




\begin{tabular}{|c|c|c|c|c|c|c|}
\hline $\begin{array}{l}\text { [Surface Conditioning }=0 \text { ] } \\
{[\text { Test method }=1] \text { * }[S \text { Water }} \\
\text { storage of the substrate }=0] \\
\text { [Surface Conditioning }=2]{ }^{*} \\
{[\text { Test method }=1]{ }^{*}[\text { Water }} \\
\text { storage of the substrate }=0]\end{array}$ & -9.747 & 12.797 & $\begin{array}{l}-.985 \\
-.762\end{array}$ & $\begin{array}{l}.325 \\
.447\end{array}$ & -34.931 & 16.441 \\
\hline
\end{tabular}

a. This parameter is set to zero because it is redundant.

b. Substrate=Adherent

c. Weighted Least Squares Regression - Weighted by Weight

\section{Table 8b}

\section{Parameter Estimates $^{\mathrm{b}, \mathrm{c}}$}

Dependent Variable: Mean Bond Strength (MPa)

\begin{tabular}{|c|c|c|c|c|c|c|}
\hline \multirow[b]{2}{*}{ Parameter } & \multirow[b]{2}{*}{ B } & \multirow[b]{2}{*}{$\begin{array}{l}\text { Std. } \\
\text { Error }\end{array}$} & \multirow[b]{2}{*}{$t$} & \multirow[b]{2}{*}{ Sig. } & \multicolumn{2}{|c|}{ 95\% Confidence Interva } \\
\hline & & & & & $\begin{array}{l}\text { Lower } \\
\text { Bound }\end{array}$ & $\begin{array}{l}\text { Upper } \\
\text { Bound }\end{array}$ \\
\hline Intercept & 37.086 & 3.268 & 11.349 & .000 & 30.617 & 43.554 \\
\hline [Surface Conditioning=0] & -9.710 & 8.975 & -1.082 & .281 & -27.477 & 8.057 \\
\hline [Surface Conditioning=1] & 10.054 & 4.349 & 2.312 & .022 & 1.445 & 18.663 \\
\hline [Surface Conditioning=2] & 10.438 & 5.336 & 1.956 & .053 & -.125 & 21.001 \\
\hline [Surface Conditioning=3] & $0^{a}$ & - & - & - & - & - \\
\hline [Test method $=1]$ & -11.322 & 3.599 & -3.146 & .002 & -18.448 & -4.197 \\
\hline [Test method=2] & -11.830 & 3.653 & -3.238 & .002 & -19.062 & -4.598 \\
\hline [Test method=3] & $0^{a}$ & - & - & - & - & - \\
\hline $\begin{array}{l}\text { [Water storage of the } \\
\text { substrate }=0 \text { ] }\end{array}$ & -6.549 & 4.592 & -1.426 & .156 & -15.639 & 2.541 \\
\hline $\begin{array}{l}{[\text { Surface Conditioning }=1]{ }^{*}[\text { Test }} \\
\text { method }=1]\end{array}$ & -21.759 & 7.662 & -2.840 & .005 & -36.927 & -6.591 \\
\hline $\begin{array}{l}\text { [Surface Conditioning }=1] \text { * [Test } \\
\text { method }=2]\end{array}$ & $0^{a}$ & - & - & - & - & - \\
\hline $\begin{array}{l}{[\text { Surface Conditioning }=2] * \text { TTest }} \\
\text { method }=1]\end{array}$ & -23.250 & 7.264 & -3.201 & .002 & -37.630 & -8.869 \\
\hline $\begin{array}{l}{[\text { Surface Conditioning }=2] * \text { TTest }} \\
\text { method }=3]\end{array}$ & $0^{a}$ & - & - & - & - & - \\
\hline $\begin{array}{l}\text { [Surface Conditioning }=2 \text { ] } \\
\text { [Water storage of the } \\
\text { substrate }=0 \text { ] }\end{array}$ & -1.403 & 20.416 & -.069 & .945 & -41.818 & 39.013 \\
\hline
\end{tabular}

a. This parameter is set to zero because it is redundant.

b. Substrate $\neq$ Adherent

c. Weighted Least Squares Regression - Weighted by Weight 
Potentially relevant studies according to initial electronic search

Independent screening by 2 reviewers

\section{Figure captions:}

Fig.

Studies included after

handsearch

$n=n$

Studies retrieved for abstract evaluati $\phi$

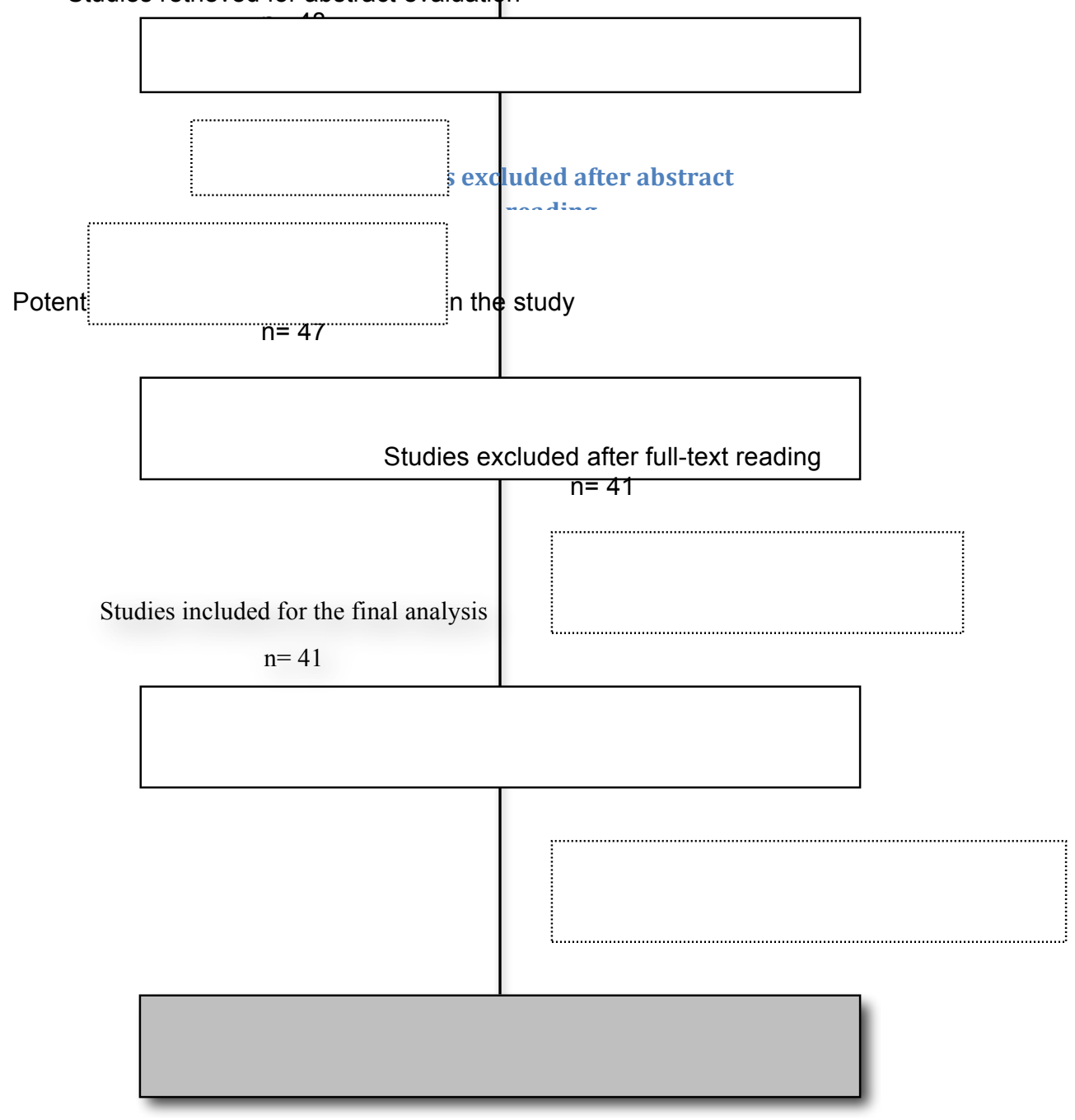


Figs 2a-f Mean bond strength (MPa) for substrate-adherent adhesion of the same kind (Substrate=Adherent) with and without thermocycling of the substrate after macroshear, macrotensile and microtensile tests.

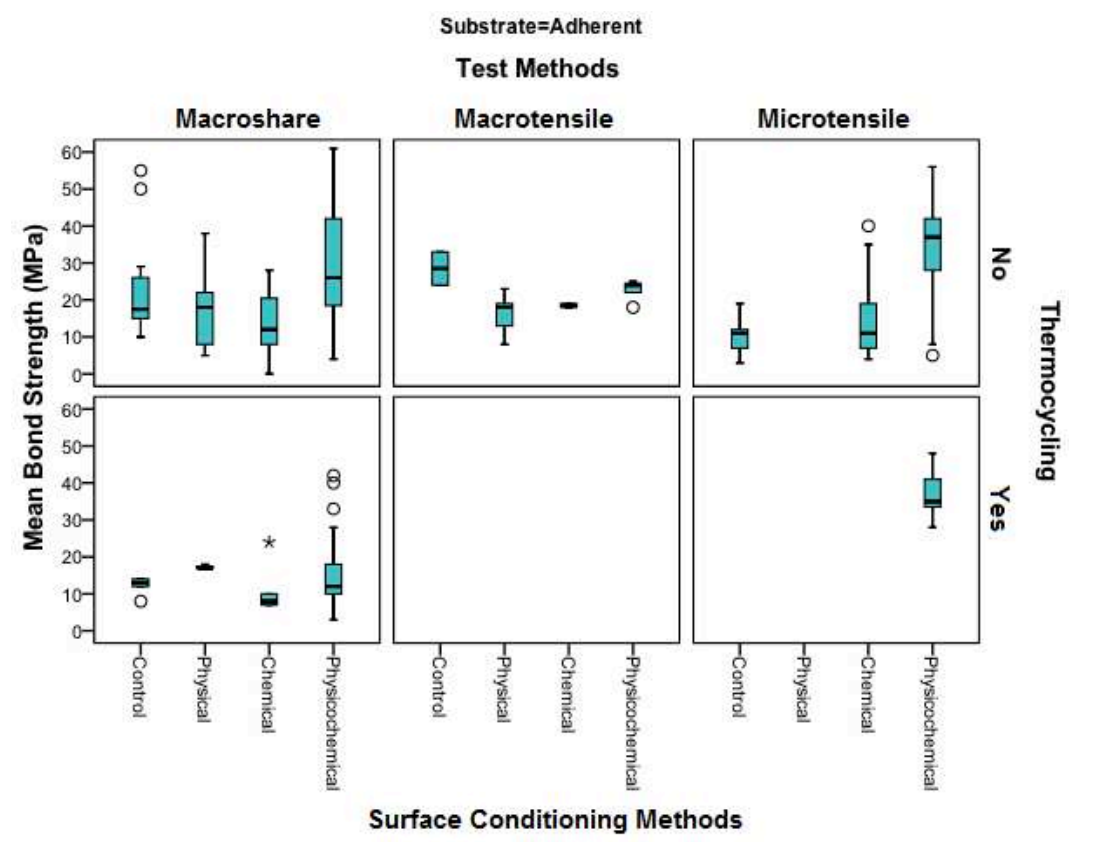

Figs 3a-f Mean bond strength (MPa) for substrate-adherent adhesion of dissimilar composites (Substrate $\neq$ Adherent) with and without thermocycling of the substrate after macroshear, macrotensile and microtensile tests.

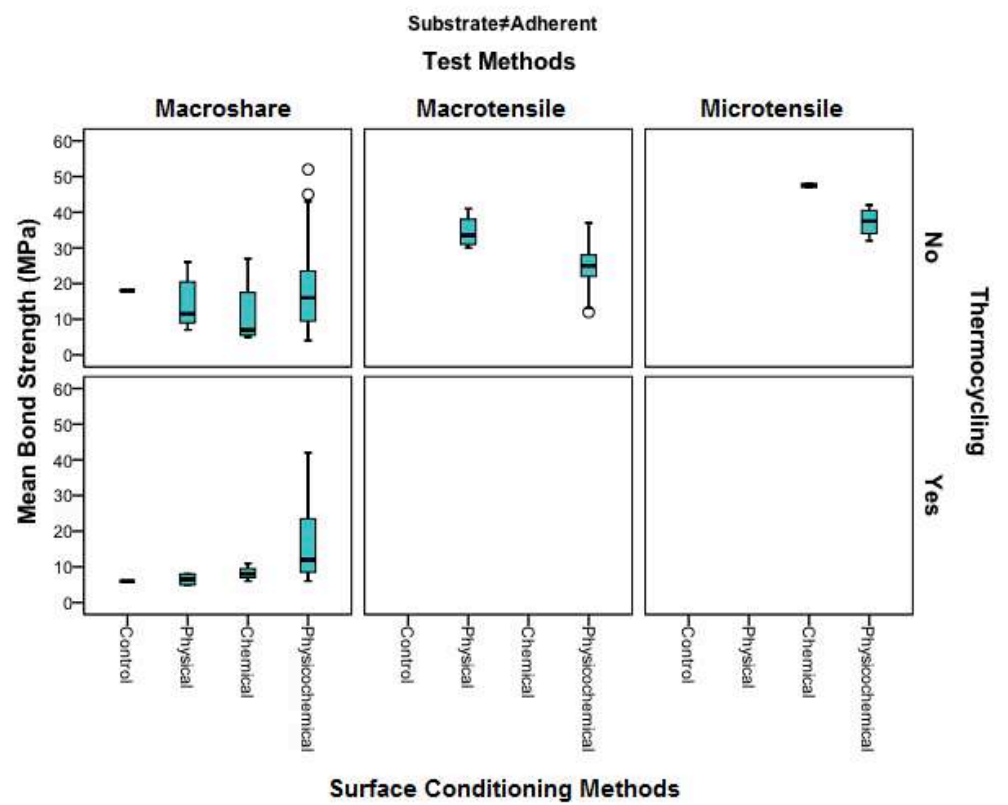


Figs 4a-f Mean bond strength (MPa) for substrate-adherent adhesion of the same kind (Substrate=Adherent) with and without water storage of the substrate after macroshear, macrotensile and microtensile tests.

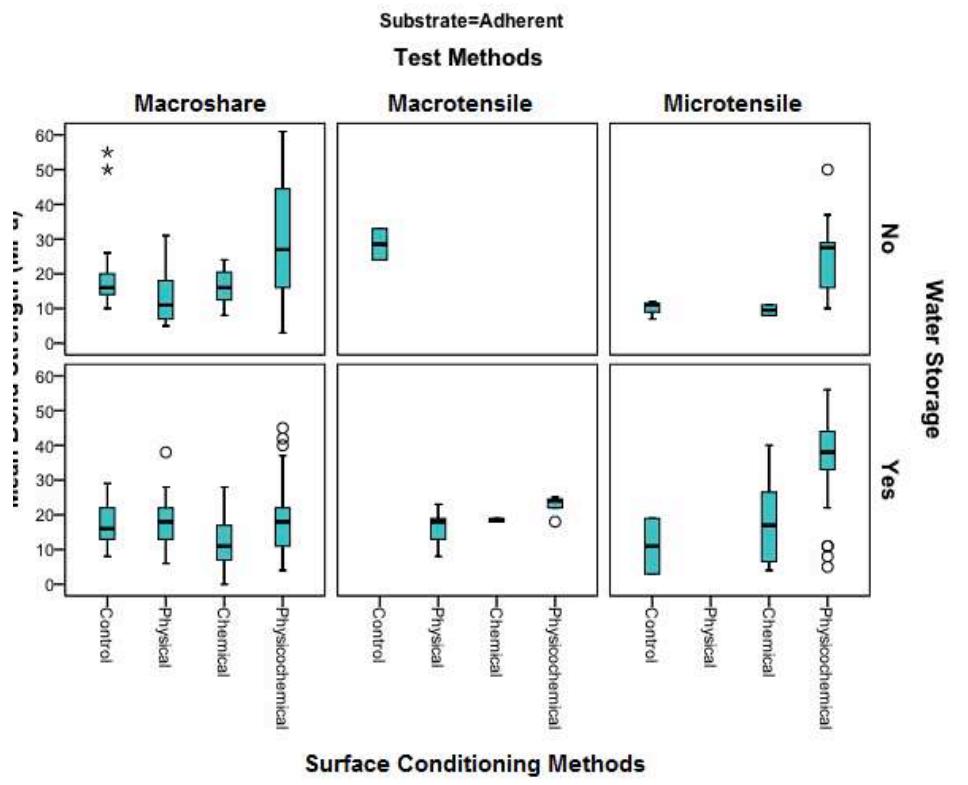

Figs. 5a-f Mean bond strength (MPa) for substrate-adherent adhesion of dissimilar composites (Substrate $\neq$ Adherent) with and without water storage of the substrate after macroshear, macrotensile and microtensile tests.

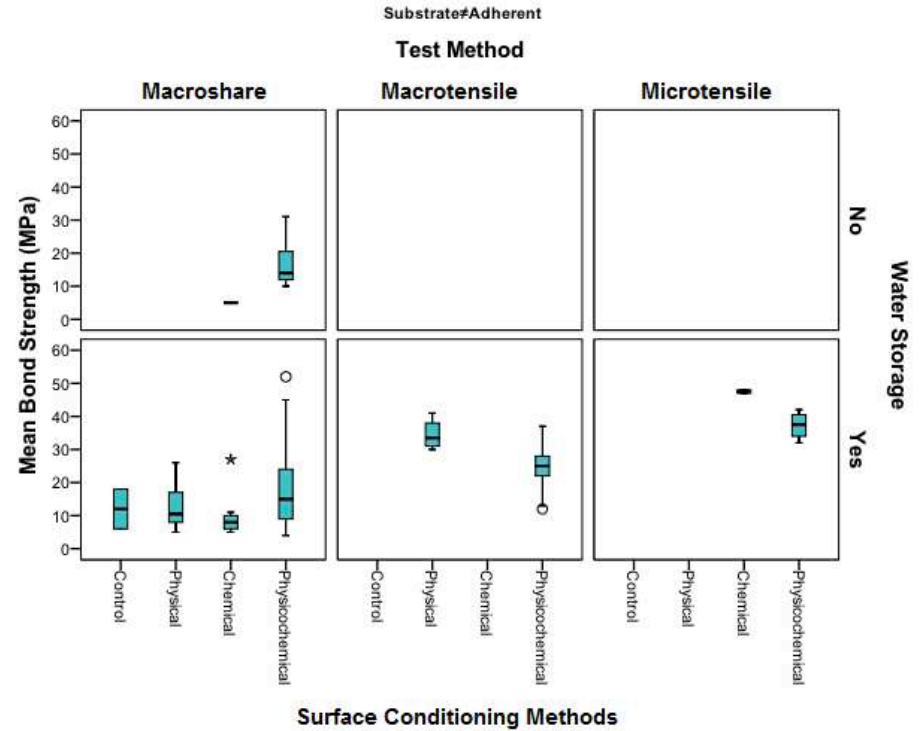


